Article

\title{
New Aspects on the Direct Solid State Polycondensation (DSSP) of Aliphatic Nylon Salts: The Case of Hexamethylene Diammonium Dodecanoate
}

\author{
Angeliki D. Mytara (D), Athanasios D. Porfyris (D), Stamatina N. Vouyiouka (D) and Constantine D. Papaspyrides * (D) \\ Laboratory of Polymer Technology, School of Chemical Engineering, National Technical University of Athens, \\ Zographou Campus, 15780 Athens, Greece; amytara@mail.ntua.gr (A.D.M.); adporfyris@mail.ntua.gr (A.D.P.); \\ mvuyiuka@central.ntua.gr (S.N.V.) \\ * Correspondence: kp@cs.ntua.gr
}

check for

updates

Citation: Mytara, A.D.;

Porfyris, A.D.; Vouyiouka, S.N.;

Papaspyrides, C.D. New Aspects on

the Direct Solid State

Polycondensation (DSSP) of Aliphatic

Nylon Salts: The Case of

Hexamethylene Diammonium

Dodecanoate. Polymers 2021, 13, 2625.

https://doi.org/10.3390/

polym 13162625

Academic Editor: Ivan Gitsov

Received: 30 June 2021

Accepted: 3 August 2021

Published: 6 August 2021

Publisher's Note: MDPI stays neutral with regard to jurisdictional claims in published maps and institutional affiliations.

Copyright: (c) 2021 by the authors. Licensee MDPI, Basel, Switzerland. This article is an open access article distributed under the terms and conditions of the Creative Commons Attribution (CC BY) license (https:// creativecommons.org/licenses/by/ $4.0 /)$
Abstract: The direct solid state polymerization (DSSP) of hexamethylene diammonium dodecanoate (PA 612 salt) was investigated for two different salt grades, fossil-based and bio-based. Aliphatic polyamide salts (such as PA 612 salt) are highly susceptible to solid melt transition (SMT) phenomena, which restrain the industrial application of DSSP. To that end, emphasis was given on reactor design, being the critical parameter influencing byproduct diffusion, amine loss and inherent DSSP kinetics. Experiments took place both at the microscale and the laboratory scale, in which two different reactors were tested in terms of bypassing SMT phenomena. The new reactor designed here proved quite successful in maintaining the solid state during the reaction. Scouting experiments were conducted in order to assess the effect of critical parameters and determine appropriate reaction conditions. Fossil-based PA 612 products proved to have a better end-group imbalance in comparison to biobased ones, which is critical in terms of achieving high molecular weight. Finally, a real DSSP process was demonstrated, starting from PA 612 salt crystals and ending with PA 612 particles.

Keywords: aliphatic polyamides; direct solid state polymerization; polycondensation water; polymerization at the microscale

\section{Introduction}

The direct solid state polymerization (DSSP) of polyamide salts has been systematically investigated in our laboratory since the late 1970s [1-30]. DSSP involves heating the solid reacting mass at a temperature below its melting point and the melting point of the final polymer product under an inert atmosphere as to allow the progression of the polycondensation, while maintaining the solid phase in the reacting mass. DSSP has been found to yield high quality products as side reactions and thermal degradation are avoided. The reason for this lies mainly in the low reaction temperatures applied. Thus, DSSP is the most appealing candidate for industrial application due to the mild reaction conditions (in terms of pressure and temperature), the absence of solvents and the simple equipment used. This renders the process both cost and environmentally friendly, especially since the products obtained present high conversion and excellent properties for relatively short reaction times $[12,17,24,26,28-30]$.

Numerous studies have appeared in the open and patent literature on the DSSP of polyamide salts. Polyamide salts combine both acid and amine groups and usually can crystallize from a solution $[7,10,11,25,29,31]$. Papaspyrides et al. have studied the DSSP of PA 126 salt (nylon ${ }^{\circledR} 126$ salt) at a temperature range up to $25^{\circ} \mathrm{C}$ below its melting point. The salt was suspended in an inert non-solvent and a distinct transition to the melt state and agglomeration of the solid crystals was clearly observed thanks to the glassware assembly employed [2,3]. The same behavior was noticed later in the same laboratory for a series of aliphatic nylon ${ }^{\circledR}$ salts including PA 26, PA 210, PA 46, PA 66, PA 410, PA 610 and PA 
$1210[7,8]$. Conversion before melt occurrence remained particularly low (approximately at $0.05-0.1$ ), clearly indicating that it is impossible to achieve polymer formation, while maintaining the solid state [7].

DSSP kinetics (in the stage prior to transition to the melt) fit well typical nucleation and growth data. The nucleation stage occurs first on the surface of the crystallites and then in the defective sites. In parallel it has been confirmed that during the initial stages of the DSSP of polyamide salts, the volatile diamine component escapes in both aliphatic (nylon ${ }^{\circledR}$ ) salts and semi-aromatic polyamide salts $[20,28,29,32,33]$. In addition, in a DSSP study on PA 66, it was discovered that diamine loss preceded water formation, thus resulting in even more defects in the salt crystal lattice, which in turn are active centers for initiation and propagation [20].

Following nucleation, the growth stage often proceeds unexpectedly. The transition to the melt state or the so-called solid melt transition (SMT) has been linked with the formation of the polycondensation water in the reacting mass. Papaspyrides et al. in a series of studies proposed a mechanism for SMT as follows: water formed during the solid state polycondensation reaction hydrates the polar groups of the hydrophilic polyamide salt. As the reaction proceeds and the amount of polycondensation water increases, the crystal structure of the salt is destroyed by the formation of highly hydrated regions. These areas have a much lower melting point and soon fall in the melt state, resulting in the experimentally observed transition of the reaction from the solid to the melt state. As the reaction proceeds further, the molecular weight increases, the hygroscopicity of the reacting system decreases and finally the solid character of the system is restored [3-10,17,24].

Further studies revealed that the occurrence of SMT is highly dependent on the inherent chemical structure of the polyamide salt. The DSSP of ethylene diammonium fumarate, ethylene diammonium maleate and hexamethylene diammonium fumarate, which have a more organized and rigid network of polar coordinating groups than the aliphatic polyamide salts, presented severe deviations from the SMT model [7,9]. In these cases, water accumulation to the solid mass was noted along with a phase separation, thus indicating a link between the occurrence of SMT and the nature of the polyamide salt and its structural organization [9]. The latter point was highlighted also in recent studies on the DSSP of semi-aromatic PA $4 \mathrm{~T}$ and PA $6 \mathrm{~T}$ polyamides [28,30]. Within the experimental conditions applied, the reacting PA 4T and PA 6T salt crystals, maintained their morphology as a whole, and no agglomeration or sticking was evident, suggesting that the reaction could proceed in true solid state.

As aliphatic polyamides are of significant commercial and industrial interest, accounting for more than $40 \%$ of total polyamide demand, many attempts have been made to overcome, manage or even exploit the transition to the melt, aiming to open the route for the industrial application of DSSP. A series of organic and metal catalysts have been tested, both as to their influence on the reaction rate and on the occurrence of SMT $[4-6,11,17,19,23,24,34]$. The presence of an effective catalyst in the DSSP of both PA 126 salt and PA 66 salt, was found to favor the diffusion of polycondensation water and the reaction is shifted to the right, while bypassing SMT phenomena $[4,5,11]$. In particular for the DSSP of PA 66 salt effective catalysts include $\mathrm{H}_{3} \mathrm{BO}_{3},(\mathrm{COOH})_{2}, \mathrm{H}_{3} \mathrm{PO}_{4}$, and $\mathrm{MgO}$. It was also found that the method applied for the incorporation of the catalyst in the reacting mass influenced the effectiveness of the catalytic action, as the coprecipitation of the catalyst along with the polyamide salt proved more effective than dry mixing, probably due to the ionic bonds of the catalyst with the polyamide monomer.

Turning to reactor aspects, it has been proposed the removal of the polycondensation water at atmospheric pressure, mentioning however that "the solid mass never completely liquifies", suggesting that some degree of agglomeration and/or partial melting is involved [35]. Papaspyrides et al. proposed initially a pre-polymerization process in a typical high pressure batch autoclave. Dry PA 66 salt was heated under autogenous pressure in the proximity of its melting point to minimize the loss of hexamethylene diamine. The process was followed by a venting stage, in which pressure release allows water removal, shifting 
the reaction to the right $[15,16]$. Later an extrusion type assembly was employed for scaling up [14]. PA 66 salt was reacted slightly above its melting point, ca. $200^{\circ} \mathrm{C}$. The machinery used was capable of handling all process stages encountered, namely melting the dry salt fed, then reacting at the melt state and finally, while the mass was solidified, completion of the reaction in the solid state. In fact, as has been mentioned already when molecular weight increases the reacting mass starts solidifying again and this would inevitably result in severe damages on any conventional equipment employed [14].

On the other hand, SSP runs have been also carried out at the micro scale and in a TGA chamber. This route ensures runs are easy to make, and thus a wide variety of valuable kinetic data at different critical parameters, such as time, temperature and gas flow rates. Historically this effort has been originating in the sixties when Volokhina et al. polymerized nylon salts, such as PA 66 and PA 6T salt in a TGA "micro" reactor. These experiments were continued in 1990s, polymerizing PA 66 in the presence of boric acid as a catalyst. It was discovered that the presence of the catalyst changes dramatically the reaction mechanism so that in this case the reaction is not any more controlled by diffusion but by intrinsic kinetics [32,33]. The same conclusion was met later, studying the DSSP reaction of semi-aromatic polyamide salts but in this case even in the absence of catalysts $[28,29]$. Finally, it was also proved that when scaling up from the TGA micro reactor to a laboratory scale reactor, the same picture was encountered but when operated at the same critical reaction parameters [30].

In conclusion, the occurrence of SMT presents a major obstacle when considering the application of DSSP in an industrial scale at least for the production of aliphatic nylon ${ }^{\circledR}$ salts. Moreover, catalysts negatively influence the purity of polyamides restricting their spectrum of applications. In fact, and to the best of our knowledge, there is no such an industrial application of a DSSP route on aliphatic polyamide salts. In our laboratory, long time effort has been spent on developing technology via which the DSSP of aliphatic nylon ${ }^{\circledR}$ salts would proceed at an adequate rate and reach an acceptable conversion, while maintaining the solid state fully during the course of the reaction. As the diffusion of the polycondensation water has be proven to be very critical to the maintenance of the solid state, our interest has been focused also on reactor design to father facilitate byproduct removal.

In this paper hexamethylene diammonium dodecanoate (PA 612) was selected towards testing such a system for the following reasons: PA 612 belongs in a category of long aliphatic chain polyamides with increasingly extensive applications and commercial interest. The lower concentration of amide bonds in PA 612 compared with PA 6 and PA 66 is accounted for a number of properties desired in industry, such as low moisture sensitivity, combined with good dimensional stability, toughness and abrasion resistance, as well as relatively high melting point and good thermal stability [36-41]. On the other hand, the low hygroscopicity of this salt renders it a good candidate for DSSP. Beyond that, considering increasing academic interest towards bio-based polyamides from renewable sources, two grades of PA 612 salts were examined in this research, one fossil-based and one partly bio-based.

\section{Materials and Methods}

\subsection{Starting Materials}

The reactants used for the preparation of polyamide 612 (PA 612) were hexamethylenediamine (HMD, Alfa Aesar, Kandel, Germany) and dodecanedioic acid (DDDA). Two different grades of DDDA were used, one fossil-based grade purchased from Alfa Aesar (purity 99\%) and a bio-based one provided by Cathay Biotechnology (Cathay, Biotechnology, Shandong, China) (purity $\geq 98.5 \%$ ). Commercial polyamide 66 (PA 66) salt from BASF (BASF, Ludwigshafen, Germany) was used as reference material for characterization purposes. Ethanol (EtOH) by Acros Organics (Schwerte, Germany) was used as a solvent for the potentiometric titration of polyamide salts. O-cresol (Merck, Hohenbrunn, Germany), phenol (Chemlab, Zedelgem, Belgium), methanol (MeOH, Fischer, Kandel, Germany), 
1,2 dichlorobenzene (ODCB) and lithium chloride ( $\mathrm{LiCl}$, Alfa Aesar) were used as solvent systems for potentiometric titration of polyamide samples. Sulfuric acid 99\% (Fluka, Seelze, Germany) was used as a solvent for viscosity measurements.

\subsection{Polyamide Salt Preparation}

PA 612 salt was prepared as described in previous research of ours [29,31]. Specifically, $66.5 \mathrm{~g}(0.288 \mathrm{~mol})$ solid DDDA were added to an aqueous solution of HMD (33.5 g, $0.289 \mathrm{~mol}$ ) of a concentration of $10 \% \mathrm{w} / \mathrm{v}$, and left to react at $50{ }^{\circ} \mathrm{C}$ under stirring for $1 \mathrm{~h}$ under reflux. The salt solution was then left to evaporate in a fume hood, washed with ethanol, dried in vacuo for $24 \mathrm{~h}\left(50^{\circ} \mathrm{C}\right)$ and the final product was collected in the form of colorless crystals.

\subsection{Direct Solid-State Polymerization (DSSP)}

\subsubsection{Micro Scale (TGA) Runs}

DSSP of PA 612 salt was first investigated at the micro scale, in a Mettler Toledo TGA/DSC 1 HT (Mettler Toledo, Columbus, OH, USA) instrument, using $100 \mu \mathrm{L}$ aluminum crucibles to simulate SSP laboratory reactor conditions. Approximately 20 to $30 \mathrm{mg}$ of dried PA 612 salt were placed in the crucible which was then sealed with a lid having a hole on the top, of $2 \mathrm{~mm}$ diameter. The samples were inserted into the TGA chamber at $30^{\circ} \mathrm{C}\left(T_{0}\right)$, preheated to $160{ }^{\circ} \mathrm{C}\left(T_{1}\right)$ at a rate of $20^{\circ} \mathrm{C} \mathrm{min}^{-1}$, left at $T_{1}$ for $15 \mathrm{~min}$ and further heated up to the nominal reaction temperature ( $\left.T_{\mathrm{DSSP}}\right)$ at a rate of $1{ }^{\circ} \mathrm{C} \mathrm{min}^{-1}$, followed by the final isothermal step at $T_{\mathrm{DSSP}}$ for periods ranging from 5 to $24 \mathrm{~h}$ ( $\left.t_{\mathrm{DSSP}}\right)$. $T_{\mathrm{DSSP}}$ was chosen to be $20-30{ }^{\circ} \mathrm{C}$ below the melting point of the salt. Nitrogen was used as the inert gas at a constant flow rate of $25 \mathrm{~mL} \mathrm{~min}^{-1}$. After the isothermal step the material was cooled to room temperature.

From the data obtained it is possible to calculate $t_{1 / 2}$, which is defined as the time at which $50 \%$ of conversion is reached [28]. The total mass loss recorded from TGA experiments is compared to the theoretical loss of water of PA 612 salt polycondensation reaction, which can be calculated stoichiometrically $(10.4 \% w / w)$, at conversion equal to 1. Amine loss is calculated as the deviation of the total mass loss from the theoretical one $[28,29]$.

\subsubsection{Laboratory Scale Runs}

Scaling up from micro scale DSSP experiments were carried out in two different laboratory scale reactors, namely Reactor 1 and 2. Reactor 1 is a commercial cylindrical autoclave by Parr Instrument Company (Parr Instrument Company, Frankfurt, Germany) $(d=3 \mathrm{~cm}, h=17.5 \mathrm{~cm})$, equipped with a gas inlet to permit preheated purge gas passing through the polymer mass during reaction. Reactor 2 is a fixed bed reactor more capable of removing the water formed. For each experiment, the reactor was filled with $10 \mathrm{~g}$ of dried PA 612 salt and purged several times with nitrogen as an inert gas at room temperature. Then nitrogen at $20 \mathrm{~mL} \mathrm{~min}^{-1}$ was set flowing through the salt and heating was started to the desired $T_{D S S P}$. However, runs even at zero flow rates were carried out. After the end of the reaction $\left(t_{\mathrm{DSSP}}=5\right.$ to $24 \mathrm{~h}$ ), the reactor was cooled in an ice bath to $T_{\text {cooling }}=40^{\circ} \mathrm{C}$.

Finally, to demonstrate the feasibility of the DSSP process, the most promising product in terms of molecular weight and end group balance was selected and subjected to post-SSP. The reaction took place in a typical fixed bed reactor at $170{ }^{\circ} \mathrm{C}$ for $4 \mathrm{~h}$. In this case, nitrogen was used only for purging and then flow rate was set at $0 \mathrm{~mL} \mathrm{~min}^{-1}$.

The nomenclature and DSSP reaction conditions all runs are presented in Table 1. 
Table 1. DSSP reaction conditions and nomenclature for all experiments.

\begin{tabular}{|c|c|c|c|}
\hline & $T_{\text {DSSP }}\left({ }^{\circ} \mathrm{C}\right)$ & $t(\mathrm{~h})$ & $\mathrm{N}_{2}$ Flow $\left(\mathrm{mL} \mathrm{min}^{-1}\right)$ \\
\hline \multicolumn{4}{|c|}{ Micro Scale DSSP } \\
\hline TGA_160_24_25 & 160 & 24 & 25 \\
\hline TGA_165_6_25 & 165 & 6 & 25 \\
\hline TGA_168_5_25 & 168 & 5 & 25 \\
\hline TGA_170_5_25 & 170 & 5 & 25 \\
\hline \multicolumn{4}{|c|}{ Laboratory Scale DSSP } \\
\hline \multicolumn{4}{|c|}{ Effect of Reactor Design: Scouting Experiments } \\
\hline R1_165_6_20 & 165 & 6 & 20 \\
\hline R2_165_6_20 & 165 & 6 & 20 \\
\hline \multicolumn{4}{|c|}{ Evaluation of Time-Temperature Profiles Tested } \\
\hline R2_160_24_20 & 160 & 24 & 20 \\
\hline R2_165_6_20 & 165 & 6 & 20 \\
\hline R2_168_5_20 & 168 & 5 & 20 \\
\hline \multicolumn{4}{|c|}{ Effect of Nitrogen Flow Rate } \\
\hline R2_165_6_20 & 165 & 6 & 20 \\
\hline R2_165_6_0 & 165 & 6 & 0 \\
\hline \multicolumn{4}{|c|}{ Demonstration of a Feasible Two-Step DSSP } \\
\hline R2_165_6_0 & 165 & 6 & 0 \\
\hline Post_SSP_170_4_0 & 170 & 4 & 0 \\
\hline
\end{tabular}

\subsection{Characterization Techniques}

\subsubsection{Fourier Transform Infrared Spectroscopy (FT-IR)}

Samples of both PA 612 salt and polymer were mixed with KBr crystals and then formed into pastilles. Spectra were recorded using a JASCO 4200 (JASCO, Gross-Umstadt, Germany) infractometer at frequencies from 4000 to $400 \mathrm{~cm}^{-1}$ with a resolution of $4 \mathrm{~cm}^{-1}$.

\subsubsection{Concentration of End Groups}

End-group determination was achieved through potentiometric titration. The deviation of the mean values was derived through duplicate measurements. The titrant used for the determination of amine end groups was $\mathrm{HClO}_{4} / \mathrm{MeOH}\left(\mathrm{N}=0.1 \mathrm{meq} \mathrm{mL} \mathrm{mL}^{-1}\right)$ and for the carboxyl groups TBAH/BeOH $\left(\mathrm{N}=0.05 \mathrm{meq} \mathrm{mL}^{-1}\right)$. For the case of PA 612 salt $0.1 \% w / v$ solutions of salt in $70 / 30 \mathrm{EtOH} /$ water were titrated. For the case of PA 612 oligomers/polymers, solutions of $0.5 \% w / v$ in Phenol/MeOH (90/10) for the determination of amine end groups and in o-cresol/ODCB $(5 \%) / / \mathrm{LiCl}(20 \%$ in $\mathrm{MeOH})(70 / 30)$ were used $[21,22,25]$.

The experimental values for the polyamide salts were compared to the theoretical ones as calculated stoichiometrically.

\subsubsection{Solution Viscometry}

The intrinsic viscosity $[\eta]$ of synthesized polyamides was measured in sulfuric acid at a concentration of $0.5 \% w / v$ in a Cannon-Fenske viscometer $\left(\mathrm{K}=0.2308 \mathrm{~mm}^{2} \mathrm{~s}^{-1}\right)$ at $25^{\circ} \mathrm{C}$. The $[\eta]$ value was obtained by the single point measurement applying Equation (1):

$$
[\eta]=\frac{\sqrt{1+1.5 \eta_{s p}}-1}{0.75 C}
$$

where $C\left(\mathrm{~g} \mathrm{~mL}^{-1)}\right.$ is the solution concentration, and $\eta_{s p}$ the solution specific viscosity $[30,42]$. The deviation of the mean values was derived through duplicate measurements. 


\subsubsection{Thermal Properties}

DSC measurements were performed on a Mettler DSC 1 STAR System. Samples of 8-10 mg were placed in a $40 \mu \mathrm{L}$ aluminum pan. PA 612 salt samples followed a single heating cycle from $30{ }^{\circ} \mathrm{C}$ to $280{ }^{\circ} \mathrm{C}$ with a heating rate of $10{ }^{\circ} \mathrm{C} \mathrm{min}-1$, while PA 612 products followed a heating-cooling-heating cycle from $30^{\circ} \mathrm{C}$ to $280^{\circ} \mathrm{C}$ with a heating and cooling rate of $20^{\circ} \mathrm{C} \mathrm{min}-1$, under nitrogen flow $\left(25 \mathrm{~mL} \mathrm{~min}^{-1}\right)$. The melting point and specific heat of fusion of polyamides were obtained by data from the 2 nd heating and the degree of crystallinity was calculated by Equation (2):

$$
X_{c}=\frac{\Delta H_{f}}{\Delta H_{o}} \%
$$

where $\Delta H_{f}\left(\mathrm{~J} \mathrm{~g}^{-1}\right)$ is the experimental specific enthalpy of fusion and $\Delta H_{o}\left(\mathrm{~J} \mathrm{~g}^{-1}\right)$ is the specific enthalpy of fusion of the $100 \%$ crystalline polymer. For PA 612 this value is equal to $258 \mathrm{~J} \mathrm{~g}^{-1}[40,41,43]$.

TGA analysis was conducted in a Mettler Toledo TGA/DSC 1 HT thermobalance between $30-550{ }^{\circ} \mathrm{C}$ with a heating rate at $10{ }^{\circ} \mathrm{C} \mathrm{min}^{-1}$, under nitrogen flow $\left(25 \mathrm{~mL} \mathrm{~min}{ }^{-1}\right)$. Approximately $8-10 \mathrm{mg}$ of each sample was placed in an alumina pan and then in the TGA chamber. Degradation temperature $T_{d}$ was obtained for the maximum mass loss rate. For PA 612 salt samples, the degradation temperature and residue at ca. $200{ }^{\circ} \mathrm{C}$ were obtained by data for the first mass loss "step" (step_1) [25]. The degradation at $5 \%,\left(T_{d, 5} \%\right)$ was obtained for all PA 612 samples as the temperature where $5 \%$ of the initial mass is lost [29].

\subsubsection{Scanning Electron Microscopy}

Scanning Electron Microscopy (SEM) was used to evaluate the morphology of the crystals. A Jeol 6300 JSM instrument was employed, with a high sensitivity secondary electron detector at $25 \mathrm{kV}$. The polyamide was coated with Au coating using a Quorum Technologies SC7620 sputter coater (Quorum Technologies, East Sussex, UK) with a sputtering time of $150 \mathrm{~s}$ at a current of $10 \mathrm{~mA}$.

\section{Results}

\subsection{Polyamide Salts Preparation}

Two different grades of PA 612 salt derived from fossil- and bio-based DDDA were prepared, reaching a high mass yield (ca. 97\%). The purity of the obtained salts and their end-group balance $\left(D=\left[\mathrm{COO}^{-}\right]-\left[\mathrm{NH}_{3}{ }^{+}\right]\right)$influence significantly the SSP polymerization degree that could be attained. Salts' characterization data are presented in Table 2, and the measured amine and carboxyl group concentrations deviated slightly from the theoretical ones (5772 meq kg-1), with the highest deviation noticed for the case of the bio-based salt, probably due to impurities of the bio-based monomer. Both PA 612 salts are well balanced in terms of end groups though. Similar data were derived from the pertinent work of Boussia et al., in which, however, the PA 612 salt was formed via a different technology route, namely by mixing ethanolic solutions of the reactants at $0{ }^{\circ} \mathrm{C}$ [25]. It is also worth noting that the $D$ values of all salts prepared in our laboratory were found much lower compared to a commercial PA 66 salt provided by BASF and used as a guiding reference.

The formation of a polyamide salt structure was confirmed through FT-IR analysis (Figure 1), as it was possible to identify peaks corresponding to ionized amine and carboxyl end groups. Specifically, the absorption at $2200 \mathrm{~cm}^{-1}$ is assigned to the stretching vibration of the ionized amine groups, while the absorption peak at $1410 \mathrm{~cm}^{-1}$ is assigned to symmetric stretching vibration of ionized carboxyl end groups. Furthermore, the weak absorption at $1670 \mathrm{~cm}^{-1}$ is attributed to $\mathrm{NH}_{3}{ }^{+}$antisymmetric stretching vibration, whereas the weak absorption at $1124 \mathrm{~cm}^{-1}$ corresponds to $\mathrm{NH}_{3}{ }^{+}$transverse rolling vibration $[15,25]$. 
Table 2. End-group concentrations of PA 612 salts.

\begin{tabular}{|c|c|c|c|c|}
\hline & $\begin{array}{c}{\left[\mathrm{NH}_{3}{ }^{+}\right]_{\text {theor }}=\left[\mathrm{COO}^{-}\right]_{\text {theor }}} \\
\left(\text { meq kg }{ }^{-1}\right)\end{array}$ & $\begin{array}{c}{\left[\mathrm{COO}^{-}\right]} \\
\left(\mathrm{meq} \mathrm{kg}^{-1}\right)\end{array}$ & $\begin{array}{c}{\left[\mathrm{NH}_{3}{ }^{+}\right]} \\
(\mathrm{meq} \mathrm{kg}\end{array}$ & $\begin{array}{c}\mathrm{D}=\left[\mathrm{COO}^{-}\right]-\left[\mathrm{NH}_{3}{ }^{+}\right] \\
\left(\mathrm{meq} \mathrm{kg}{ }^{-1}\right)\end{array}$ \\
\hline $\begin{array}{c}\text { Fossil-based PA } \\
612 \text { salt }\end{array}$ & 5772 & $5740 \pm 110$ & $5680 \pm 90$ & 60 \\
\hline $\begin{array}{l}\text { Partly biobased } \\
\text { PA } 612 \text { salt }\end{array}$ & 5772 & $5790 \pm 100$ & $5670 \pm 22$ & 120 \\
\hline $\begin{array}{c}\text { Boussia et al. } \\
\text { PA612 salt [25] }\end{array}$ & 5772 & $5580 \pm 100$ & $5720 \pm 60$ & -140 \\
\hline $\begin{array}{c}\text { Commercial PA } \\
66 \text { salt }\end{array}$ & 7620 & $8170 \pm 170$ & $7650 \pm 170$ & 520 \\
\hline
\end{tabular}

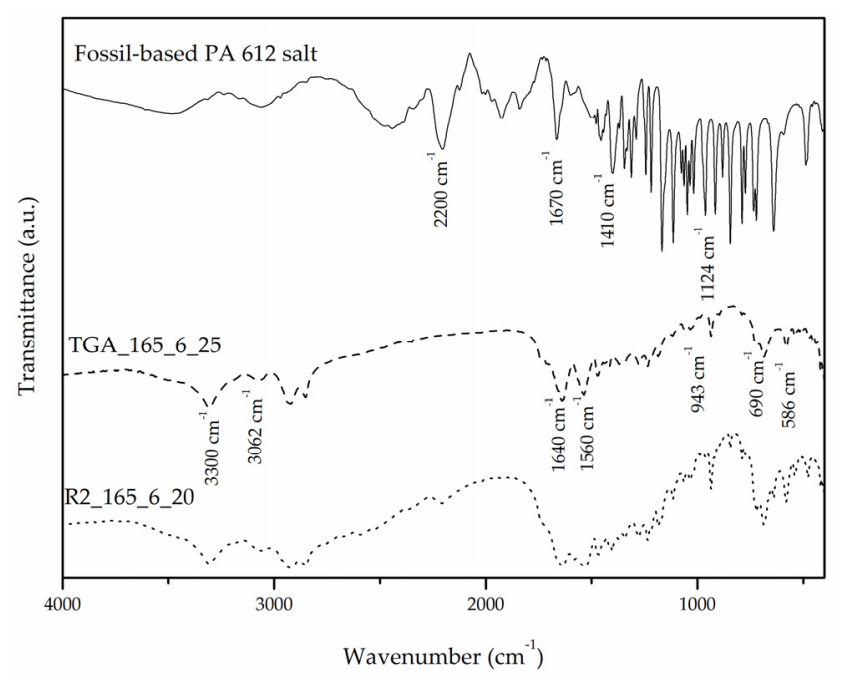

(a)

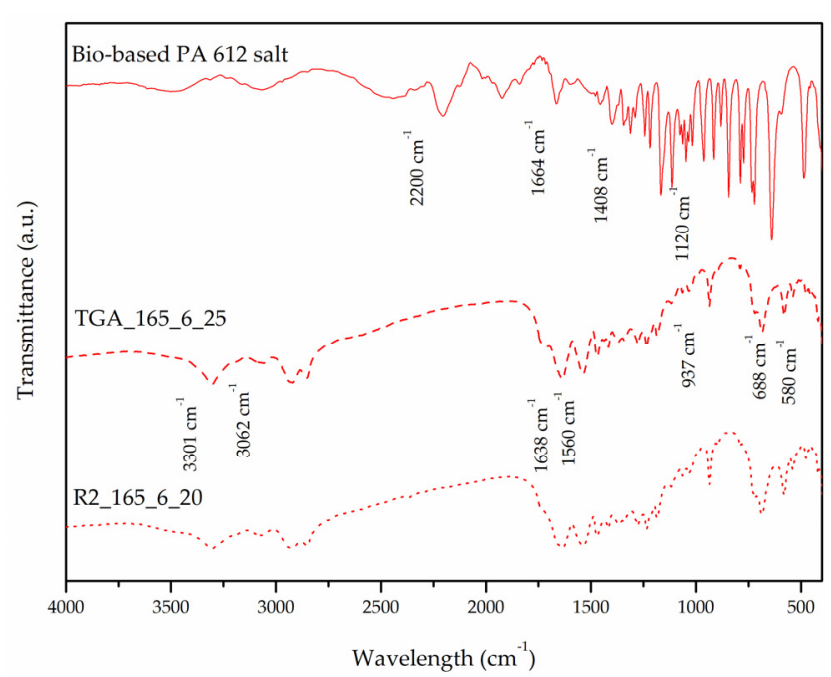

(b)

Figure 1. FT-IR spectra of the PA 612 salts and some characteristic DSSP products from both micro scale and laboratory scale runs. (a) Fossil- based grade and (b) bio-based grade.

The thermal properties of the salts prepared were studied. Based on DSC analysis, it was observed that both salts have similar melting temperatures at $189^{\circ} \mathrm{C}$ (Table 3). This value is very close to that found in the pertinent work of Boussia et al. $\left(T_{m}=185^{\circ} \mathrm{C}\right)$ [25]. On the other hand, the DSC curves revealed that following PA 612 salts melting another broad endothermic peak appears at higher temperatures (Figure 2) This broad peak corresponds to the subsequent melt polymerization of the salt in harmony with PA 66 salt, as an example [28].

In the DSC curves of both grades, it was also possible to observe an additional endothermic peak at $162-163{ }^{\circ} \mathrm{C}$ for both PA 612 salt grades, which, however, disappears after heat treatment (Figure 2). This behavior has been also observed before in the case of other aliphatic polyamide salts attributed to the accommodation of a polar solvent (i.e., ethanol, water) in the crystal lattice arrangement during salt formation [44].

Focusing more to the TGA curves of both grades (Figure 3), one can observe two mass loss steps: the first step $\left(T_{\text {step } 1}\right)$ occurred approximately at $170-230^{\circ} \mathrm{C}$ with a maximum loss at $197^{\circ} \mathrm{C}$. This step can be attributed to melting and the subsequent polymerization of the salt. The evaporation of the polycondensation water during the reaction leads to the residue recorded on the TGA graphs (84\% for the fossil-based and 83\% for the bio-based PA 612 salt). To these losses an additional loss of the volatile diamine preceding the polymerization must be added. In other words, the mass loss recorded in the first step, exceeds the theoretical 
mass loss (equal to $10.4 \%$ ), attributed to removal of polycondensation water and calculated stoichiometrically by Equation (3):

$$
\mathrm{m}_{\mathrm{H}_{2} \mathrm{O}}=\frac{2 \times \mathrm{Mr}_{\mathrm{H}_{2} \mathrm{O}}}{\mathrm{Mr}_{\text {salt }}}
$$

Finally, the second loss step $\left(T_{\text {step } 2}\right)$ occurs at approximately $450-460{ }^{\circ} \mathrm{C}$ and is attributed to the thermal degradation of the polymer formed during the TGA run $[25,28]$.

Table 3. Thermal properties of PA 612 salts (DSC single heating, TGA).

\begin{tabular}{|c|c|c|c|c|c|}
\hline & $\begin{array}{c}T_{m} \\
\left({ }^{\circ} \mathrm{C}\right)\end{array}$ & $\begin{array}{c}\Delta H_{m} \\
\left(\mathrm{~J} \mathrm{~g}^{-1}\right)\end{array}$ & $\begin{array}{c}T_{\text {step } 1} \\
\left({ }^{\circ} \mathrm{C}\right)\end{array}$ & $\begin{array}{c}T_{\text {step } 2} \\
\left({ }^{\circ} \mathrm{C}\right)\end{array}$ & $\begin{array}{c}\mathrm{m}_{\text {step_1 }} \\
(\%)\end{array}$ \\
\hline Fossil-based PA 612 salt & 189 & 167 & 199 & 449 & 84 \\
\hline Bio-based PA 612 salt & 189 & 175 & 197 & 461 & 83 \\
\hline
\end{tabular}

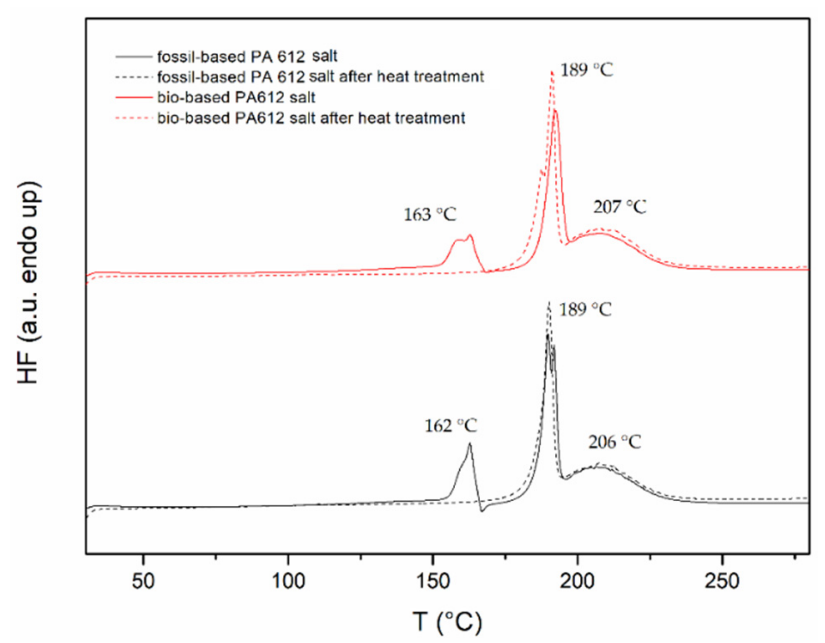

Figure 2. DSC graphs of fossil- and bio-based PA 612 salts.

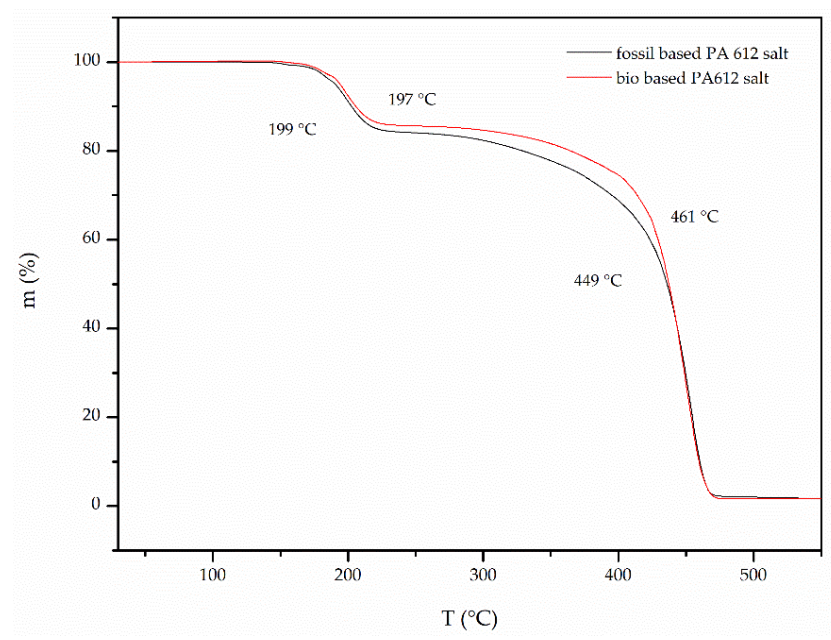

Figure 3. TGA graphs of fossil- and bio-based PA 612 salts.

Finally, the morphology of the fossil salt crystals was examined via SEM microscopy (Figure 4). For both magnifications used, crystals were characterized by sharp edges and smooth surfaces. 


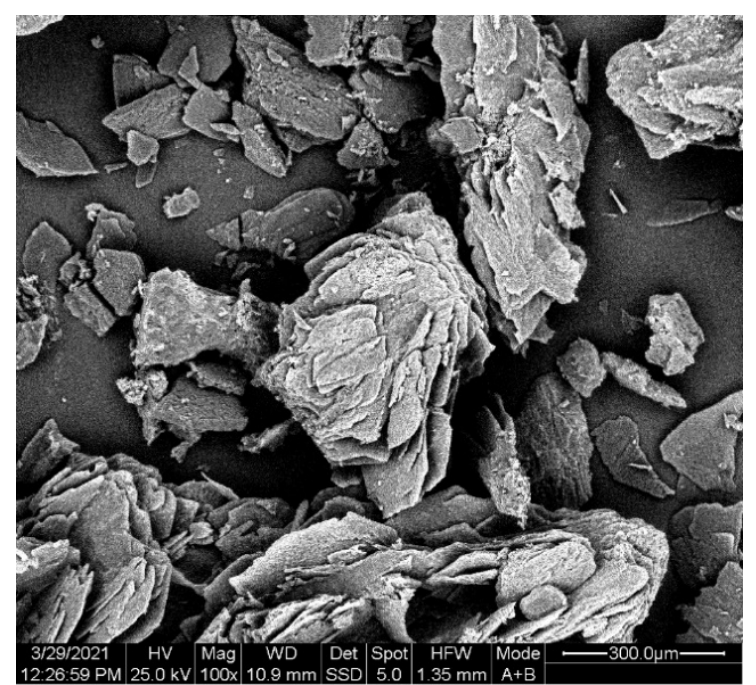

(a)

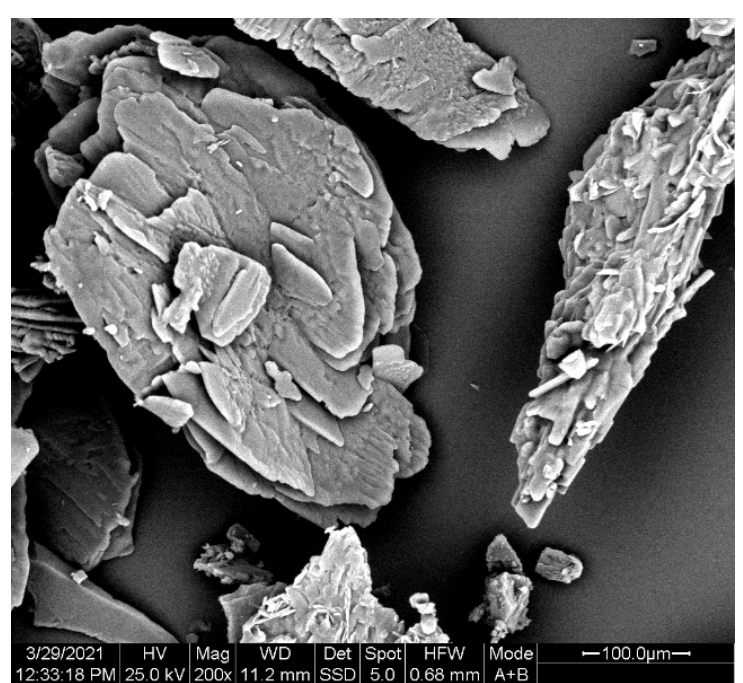

(b)

Figure 4. SEM images of PA 612 salt. (a) magnification $100 \times$ and (b) magnification $200 \times$.

\subsection{DSSP in Micro Scale}

\subsubsection{TGA Runs}

The DSSP temperature in micro scale runs was fixed at $160{ }^{\circ} \mathrm{C}, 165^{\circ} \mathrm{C}, 168{ }^{\circ} \mathrm{C}$ and $170{ }^{\circ} \mathrm{C}$, i.e., $20-30{ }^{\circ} \mathrm{C}$ below the salt melting point), also to avoid as much as possible the appearance of solid-melt transition (Section 2.3.1 and Table 1).

It must be noted here that at the end of the DSSP runs, the morphology of the final product was always carefully examined, at least macroscopically. For the fossil-based PA 612 salt, samples polymerized at $160^{\circ} \mathrm{C}$ and $165^{\circ} \mathrm{C}$ maintained the solid state and were received in the form of solid crystals. Samples polymerized at $168{ }^{\circ} \mathrm{C}$ and $170{ }^{\circ} \mathrm{C}$ fell completely in the molten state and were received as a bulk material.

Turning to the partly bio-based PA 612 salt, samples polymerized at $160^{\circ} \mathrm{C}$ and $165^{\circ} \mathrm{C}$ retained macroscopically the solid state while in samples polymerized at $168{ }^{\circ} \mathrm{C}$ partial melting and agglomeration was noticed. Finally, samples polymerized at $170{ }^{\circ} \mathrm{C}$ melted completely and were received as a bulk material similarly to the fossil-based analogue.

The nature of the salt, fossil- vs. bio-based, has been found to also play a significant role in reaction kinetics (Figure 5, Table 4). Under the same experimental conditions, the fossil-based PA 612 salt has been found to react at a higher rate than the bio-based salt. For example, at $165^{\circ} \mathrm{C}$, the fossil-based salt reaches plateau at $4 \mathrm{~h}$ and exhibits a $\mathrm{t}_{1 / 2}$ value at $1.8 \mathrm{~h}$, while at the same temperature the bio-based salt reaches plateau at $5 \mathrm{~h}$ and exhibits a $\mathrm{t}_{1 / 2}$ value at $3.1 \mathrm{~h}$.

Table 4. Mass loss and $t_{1 / 2}$ for the DSSP of fossil-based and bio-based PA 612 salt.

\begin{tabular}{cccc}
\hline Salt Grade & $\begin{array}{c}\boldsymbol{T}_{\mathbf{D S S P}} \\
\left({ }^{\circ} \mathbf{C}\right)\end{array}$ & $\begin{array}{c}\mathbf{m}_{\text {loss }} \\
(\mathbf{\%})\end{array}$ & $\begin{array}{c}\mathbf{t}_{\mathbf{1}} \\
\mathbf{( h )}\end{array}$ \\
\hline & 160 & 12.7 & 3.1 \\
Fossil-based PA 612 salt & 165 & 11.9 & 1.8 \\
& 168 & 11.7 & 1.4 \\
& 170 & 11.9 & 1.2 \\
\hline & 160 & 11.6 & 5.3 \\
Bio-based PA 612 salt & 165 & 10.6 & 3.1 \\
& 168 & 11.3 & 1.0 \\
& 170 & 11.8 & 1.1 \\
\hline
\end{tabular}




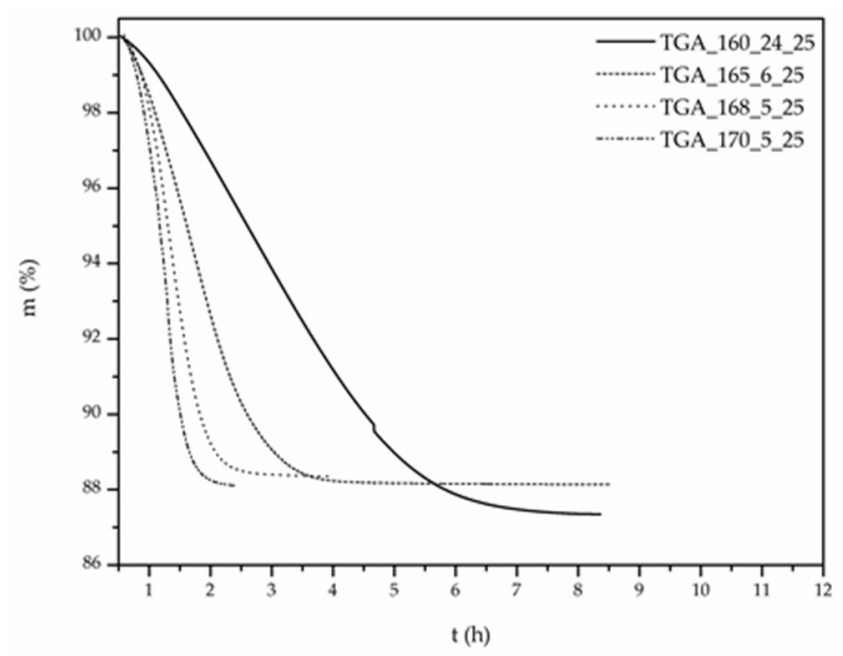

(a)

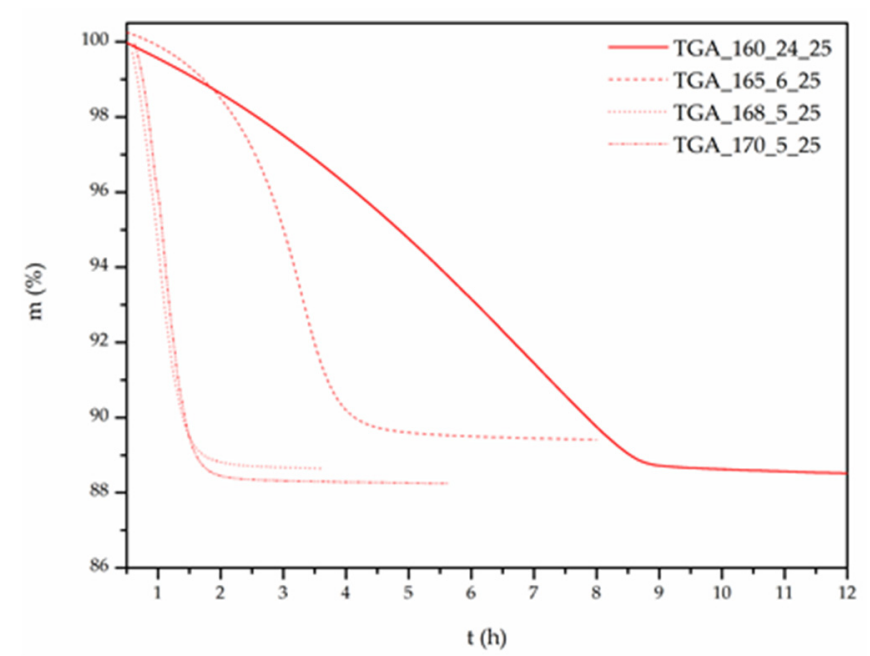

(b)

Figure 5. DSSP curves of (a) fossil-based and (b) bio-based PA 612 salt.

The aforementioned difference is in complete harmony with the noticed lag in the appearance of the SMT as discussed above, verifying once more the mechanism suggested for correlating the SMT phenomenon with the accumulation of the water formed during the reaction, i.e., the faster the reaction the earlier the SMT $[4,5]$.

Turning to the additional loss of the volatile diamine during the polymerization, diamine loss curves versus reaction temperature (Figure 6) were found to follow a " $U$ " shape for both monomer grades. Higher loss values at low temperatures are observed, then reaching a minimum, and increasing again with increasing reaction temperature. Obviously, in the regime of the low temperatures longer reaction times are required together with concurring amine loss. At the other end, at high temperatures, amine sublimation increases too. At the intermediate region amine loss seems to be "optimized".

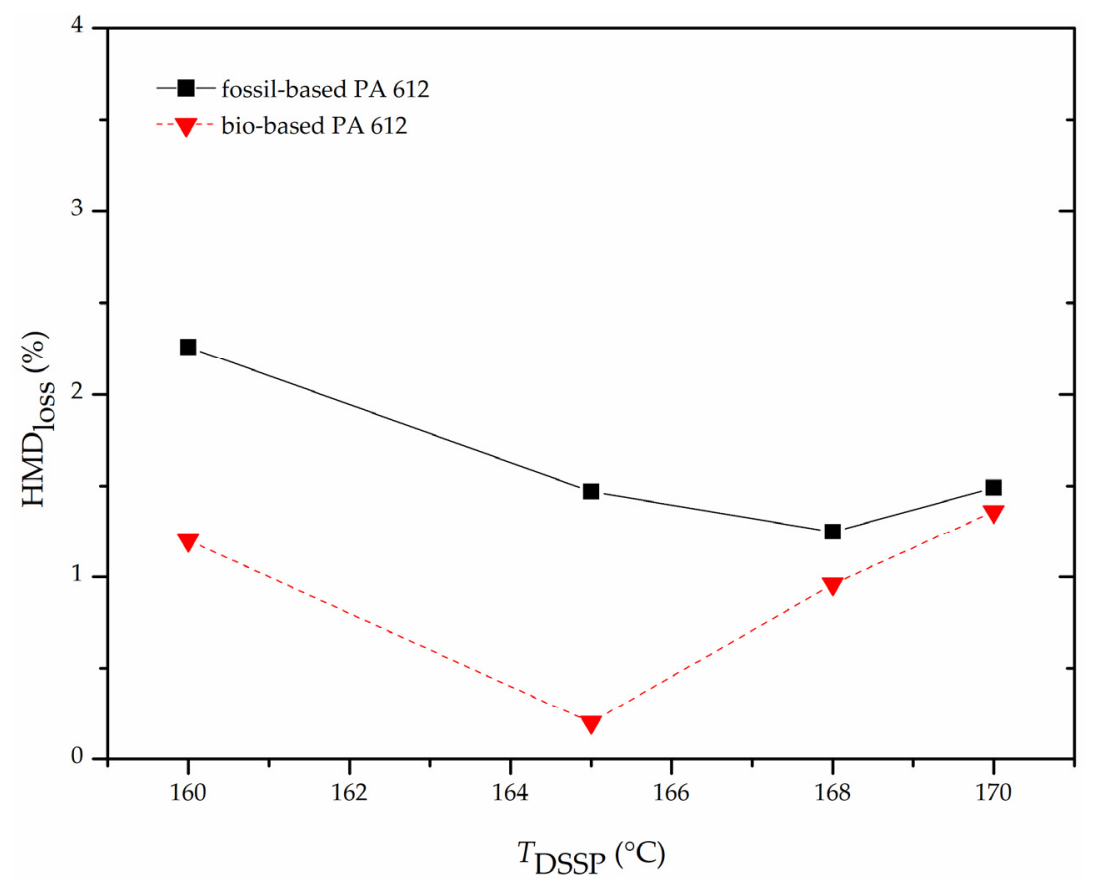

Figure 6. DSSP diamine loss for fossil-based and bio-based PA 612 salt.

It must be emphasized here that the reaction temperature is a very critical parameter in DSSP as it influences significantly both reaction mechanism and rate $[2,3,12,32,33]$. As 
has been observed for the fossil-based PA 612 salt, a small temperature increase from $165^{\circ} \mathrm{C}$ to $168^{\circ} \mathrm{C}$ leads the reaction to fully fall to the melt state, changing completely the reaction mechanism. Interesting to note is that a $5^{\circ} \mathrm{C}$ rise from $160{ }^{\circ} \mathrm{C}$ to $165{ }^{\circ} \mathrm{C}$ leads to a $42 \%$ decrease in $t_{1 / 2}$. This decrease in $t_{1 / 2}$ is even higher (61\%) when increasing the temperature to $170{ }^{\circ} \mathrm{C}$ but here the reaction kinetics/mechanism is different as the reaction falls to the melt state. A similar effect on reaction mechanism, has been observed also for a $3{ }^{\circ} \mathrm{C}$ temperature increase (from $165^{\circ} \mathrm{C}$ to $168^{\circ} \mathrm{C}$ ) for the bio-based PA 612 salt (DSSP to partial melting). Finally, Papaspyrides et. Al, studying the DSSP of the PA 126, noticed the same performance, together with solid-melt transition, for only $2{ }^{\circ} \mathrm{C}$ temperature increase $\left(126^{\circ} \mathrm{C}\right.$ to $\left.128^{\circ} \mathrm{C}\right)[2,3]$.

\subsubsection{Characterization of TGA Products}

In all runs the formation of a polyamide structure was confirmed through FT-IR analysis (Figure 1). More specifically, all spectra included the absorptions at approximately $3300 \mathrm{~cm}^{-1}$ (hydrogen-bonded-NH stretching vibration-Amide Band I), at approximately $3062 \mathrm{~cm}^{-1}$ (Amide B overtone of Amide II), at $1640 \mathrm{~cm}^{-1}$ (-C-CO stretching vibrationAmide Band I), at $1540 \mathrm{~cm}^{-1}$ (-CN stretching vibration and CONH bend-Amide Band II), at $940 \mathrm{~cm}^{-1}$ (-C=O stretching vibration-Amide Band IV), at $690 \mathrm{~cm}^{-1}$ (-NH out of plane bend) and at $586 \mathrm{~cm}^{-1}$ (-CO out of plane bend) [25,45-48].

Turning to thermal properties, the melting points of the formed polyamides are in the range from 212 to $214^{\circ} \mathrm{C}$ for the fossil-based samples and from 214 to $217^{\circ} \mathrm{C}$ for the bio-based ones. These values are slightly lower than commercial samples being in the range of $217-220^{\circ} \mathrm{C}$. It is worth noting that bio-based samples exhibit slightly higher melting points than fossil based while crystallinity values show no significant difference (23-24\% for the fossil-based samples and 20-21\% for the bio-based samples).

Typical DSC curves for both grades are given in Figure 7. All samples present a broad endotherm at $\left(190-200^{\circ} \mathrm{C}\right)$ which corresponds to the melting of defective or metastable crystals. This is followed by a small exothermic crystal rearrangement. Finally, at $212-217^{\circ} \mathrm{C}$ a sharp endotherm corresponds to the melting of the polyamide. This behavior has been published already and is common for long chain aliphatic polyamides [25,46-49].

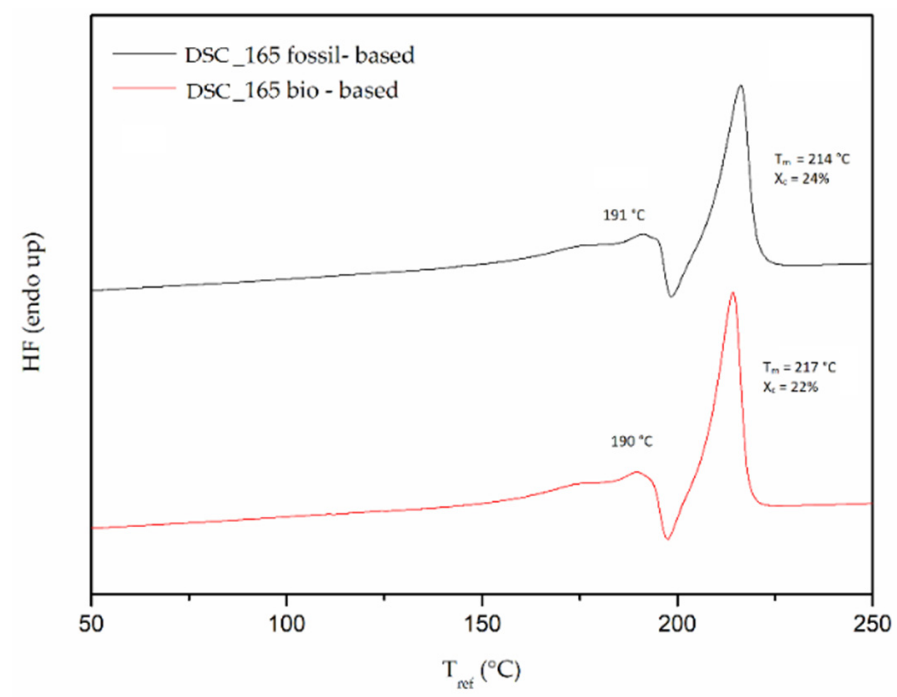

Figure 7. DSC curves of microscale DSSP products at $165^{\circ} \mathrm{C}$.

Finally, degradation temperatures are increased for all biobased samples $\left(445-449^{\circ} \mathrm{C}\right)$ when compared to fossil-based ones $\left(439-445^{\circ} \mathrm{C}\right.$ ), and the same trend is followed for $T_{d, 5 \%}$ (378-395 ${ }^{\circ} \mathrm{C}$ for bio-based compared to $372-378{ }^{\circ} \mathrm{C}$ for fossil-based). These values, while demonstrating good thermal stability, are significantly lower than values presented in literature which are around $428{ }^{\circ} \mathrm{C}$ for $T_{d, 5 \%}$ and $460^{\circ} \mathrm{C}$ for degradation temperature [25]. Shorter molecular size might be correlated to this observation. 


\subsection{DSSP in Laboratory Scale}

The aforementioned microscale polymerizations (discussed in Section 3.2.1) were carried out in laboratory scale in an attempt to avoid SMT during the reaction but also to achieve a reasonable reaction rate. Based on the pertinent findings the reaction temperature was set at 160,165 and $168^{\circ} \mathrm{C}$; however, taking into account that only the bio-based salt survived complete melting at $168^{\circ} \mathrm{C}$.

\subsubsection{Effect of Reactor Design: Scouting Experiments}

The goal here was to compare the two different reactors in terms of maintaining the solid character of the reacting mass during the course of the reaction and bypassing SMT phenomena.

Both fossil and bio-based salts were tested. All experiments were run at the same experimental conditions, namely at $165{ }^{\circ} \mathrm{C}$ and for $6 \mathrm{~h}$ (experiments R1_165_6_20 and R2_165_6_20, Table 1). Difference in scale was 1200 and 600 times larger for reactors R1 and $\mathrm{R} 2$ respectively.

Nitrogen flow was set to $20 \mathrm{~mL} \mathrm{~min}^{-1}$ close to that in the TGA chamber $\left(25 \mathrm{~mL} \mathrm{~min}^{-1}\right)$. However, very different flowing conditions apply as in the TGA runs the nitrogen flows above the aluminum pan with the hole on the cover [28,29] whereas in R1 and R2 nitrogen passes through the reacting mass.

Turning to the results it was clear, even macroscopically, that Reactor 1 products, for both grades, had been passed through a melt state. This contradicts microscale results, as products polymerized there, at $165^{\circ} \mathrm{C}$, maintained the solid state. On the contrary, in Reactor 2 products, for both salt grades and at $165^{\circ} \mathrm{C}$ the morphology of the crystals was maintained. This will be discussed in detail in Section 3.3.2. Thus, it has been proved again here the critical role of the reactor design in DSSP [12,24] since all other reaction conditions/critical parameters were the same. In other words, in Reactor 1 DSSP proceeds clearly through melt intermediate stages, even at reaction temperatures much lower than the salt melting point, as has been demonstrated by Papaspyrides et al. [2-7,12,17,24]. On the contrary, in Reactor 2, no distinct transition to the melt state occurs, leading us to believe that DSSP proceeds in true solid state $[7,17,24,28-30]$.

FT-IR analysis (Figure 1) confirmed polymer formation as the Amide Band I and Amide Band II absorptions are apparent in the spectra for all products from both reactors.

Turning to the molecular size of the DSSP products, in Table 5 the calculated number average molecular weight $\overline{\mathrm{M}_{\mathrm{n}}}$ is quoted, based on both end-group concentrations presented graphically in Figure 8. Intrinsic Viscosity $([\eta])$ data are also given for comparison.

A considerable difference in performance between the two alternative reactors is noticed. For Reactor 1 the molecular weight achieved for both grades is higher as shown also from the viscosity data (Table 5, Figure 8). In fact, the reaction has proceeded with a higher rate in the case of the R1 Reactor due to the appearance of an intermediate melt stage accelerating conversion, i.e., where a fast melt kinetics mode prevails. This is also due to the better imbalance between amine and carboxyl groups $D$ in comparison with Reactor 2.

In the Experimental Part it has been mentioned that: "Reactor 2 is a fixed bed reactor more capable of removing the water formed". However, this design also facilitates diamine escape. In fact, $\mathrm{HMD}$ vapor pressure $\left(200 \mathrm{~Pa}\right.$ at $\left.50{ }^{\circ} \mathrm{C}\right)$, is particularly high at $40{ }^{\circ} \mathrm{C}$ below its boiling point $\left(205^{\circ} \mathrm{C}\right)$ and therefore the amine tendency to switch to the gas phase dominates the process. In other words, $D$ becomes larger in $\mathrm{R} 2$ leading to lower conversion (Table 6). Thus, maintenance of the solid state according to the predominating nucleation and growth model is observed at the expense of conversion [8,9].

As to their thermal properties (Table 6), Reactor 1 products compared with those of Reactor 2 show similar values while DSC curves present double melting phenomena as has been observed in the microscale experiments (and to be discussed again in Section 3.3.2.1). 
Table 5. Effect of reactor design: molecular size and end-group imbalance of R1 and R2 products.

\begin{tabular}{|c|c|c|c|c|c|c|}
\hline & \multicolumn{2}{|c|}{$\begin{array}{c}{[\eta]} \\
\left(\mathrm{dL} \mathrm{g}^{-1}\right)\end{array}$} & \multicolumn{2}{|c|}{$\begin{array}{c}\overline{\mathbf{M}_{\mathbf{n}}} \\
\left(\mathrm{kg} \mathrm{mol}^{-1}\right) *\end{array}$} & \multicolumn{2}{|c|}{$\begin{array}{c}\mathrm{D}=[\mathrm{COOH}]-\left[\mathrm{NH}_{2}\right] \\
\left(\mathrm{meq} \mathrm{kg}^{-1}\right)\end{array}$} \\
\hline & fossil & bio & fossil & bio & fossil & bio \\
\hline R1_165_6_20 & $0.713 \pm 0.010$ & $0.684 \pm 0.021$ & 5400 & 5800 & 143 & 267 \\
\hline R2_165_6_20 & $0.251 \pm 0.020$ & $0.387 \pm 0.021$ & 1300 & 2700 & 217 & 402 \\
\hline
\end{tabular}

$* \overline{\mathbf{M}_{\mathbf{n}}}$ was calculated by end-group determination.

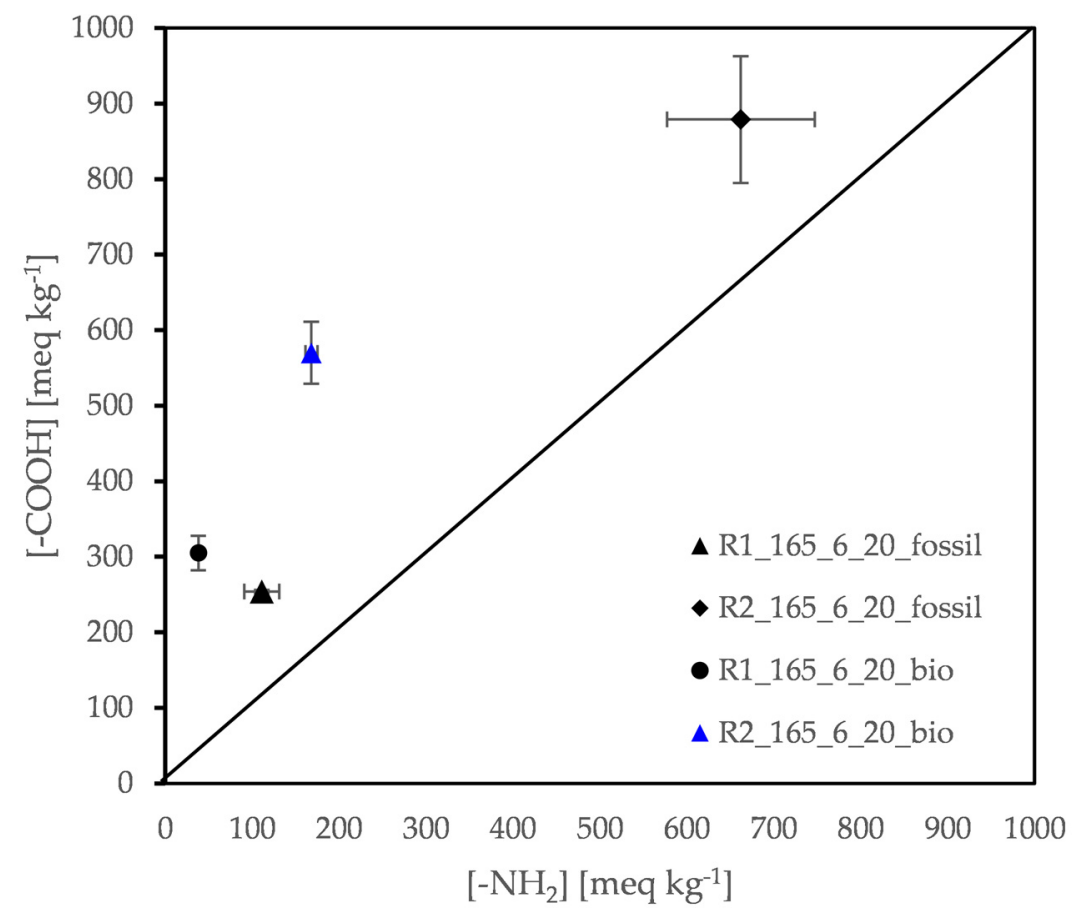

Figure 8. Effect of reactor design: amine and carboxyl end-group concentration of R1 and R2 products.

Table 6. Effect of reactor design: thermal properties of R1 and R2 products.

\begin{tabular}{|c|c|c|c|c|c|c|c|c|c|c|c|c|}
\hline & \multicolumn{2}{|c|}{$\begin{array}{l}T_{m} \\
\left({ }^{\circ} \mathrm{C}\right)\end{array}$} & \multicolumn{2}{|c|}{$\begin{array}{c}\Delta H_{m} \\
\left(\mathrm{~J} \mathrm{~g}^{-1}\right)\end{array}$} & \multicolumn{2}{|c|}{$\begin{array}{c}X_{c} \\
(\%)\end{array}$} & \multicolumn{2}{|c|}{$\begin{array}{c}T_{d} \\
\left({ }^{\circ} \mathrm{C}\right)\end{array}$} & \multicolumn{2}{|c|}{$\begin{array}{l}T_{d, 5 \%} \\
\left({ }^{\circ} \mathrm{C}\right)\end{array}$} & \multicolumn{2}{|c|}{$\begin{array}{c}\text { Residue } \\
(\%)\end{array}$} \\
\hline & fossil & bio & fossil & bio & fossil & bio & fossil & bio & fossil & bio & fossil & bio \\
\hline R1_165_6_20 & 216 & 213 & 53 & 69 & 20 & 27 & 460 & 475 & 378 & 378 & 3 & 3 \\
\hline R2_165_6_20 & 217 & 217 & 48 & 58 & 18 & 22 & 457 & 454 & 378 & 379 & 3 & 3 \\
\hline
\end{tabular}

\subsubsection{DSSP in Reactor 2}

\subsubsection{Evaluation of Time-Temperature Profiles Tested}

The performance of Reactor 2 was further studied in the range of $160-168{ }^{\circ} \mathrm{C}$ following time-temperature profiles extracted from the microscale data (Table 1). Thus, time was varied in the range of 5 to $24 \mathrm{~h}$ with decreasing trend as temperature was increased. Nitrogen flow was set in all runs at $20 \mathrm{~mL} \mathrm{~min}^{-1}$. Both fossil-and bio-based salts were tested for comparison. The goal was to optimize DSSP reaction in Reactor 2, always in terms of molecular size while maintaining the solid state. In this context, for both fossiland bio-based salts the following behavior was observed:

At $160^{\circ} \mathrm{C}$ for $24 \mathrm{~h}$ the reaction proceeded clearly in the solid state. The same applies at $165{ }^{\circ} \mathrm{C}$ for $6 \mathrm{~h}$ and at $168{ }^{\circ} \mathrm{C}$ for $5 \mathrm{~h}$. The latter behavior at $168{ }^{\circ} \mathrm{C}$ is in agreement with the TGA runs but only for the bio-based salt while the fossil one melted completely (Section 3.2.1). This can be correlated again to the fact that SMT is avoided at the expense of conversion as the TGA $t_{1 / 2}$ data clearly confirm (Table 4). In conclusion the Reactor 2 seems to play a very critical role in maintaining the solid state. 
The aforementioned morphology observations at $165^{\circ} \mathrm{C}$ and $168^{\circ} \mathrm{C}$ were further supported via SEM microscopy. The more "sensitive" fossil-based products were considered here (Figure 9) in comparison with Figure 4 where the starting materials were examined. In all cases and at all magnifications employed the maintenance of the solid state is evident. Equally important all particles present sharp edges while a variety of cracks and holes is observed on the surface of the crystals, in contrast with the smooth surface of the starting material (Figure 4). Obviously, the latter is due to the gradual release of the polycondensation water before SMT.

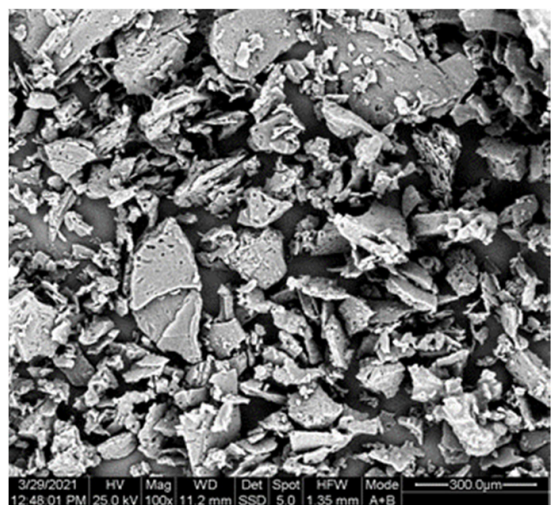

(a)

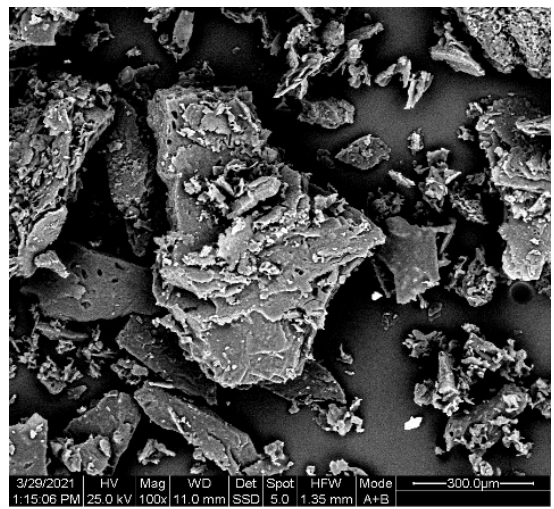

(d)

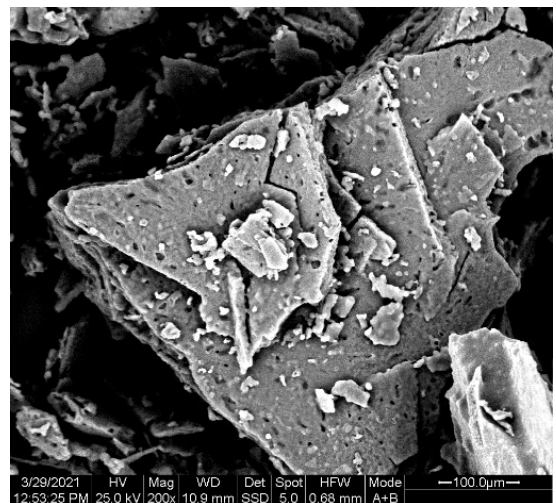

(b)

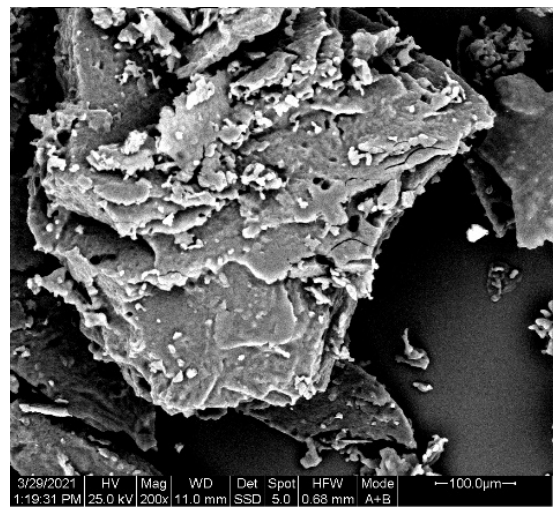

(e)

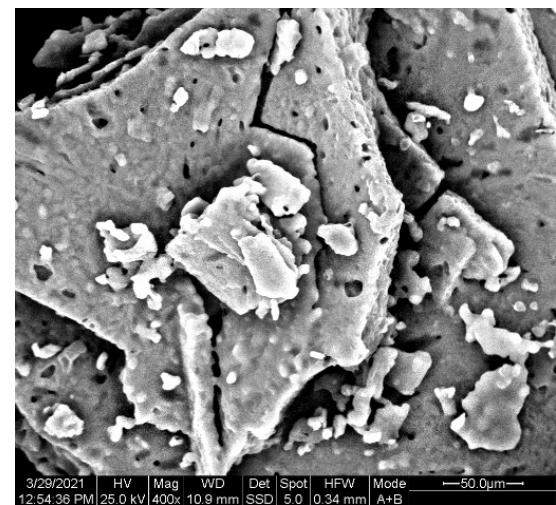

(c)

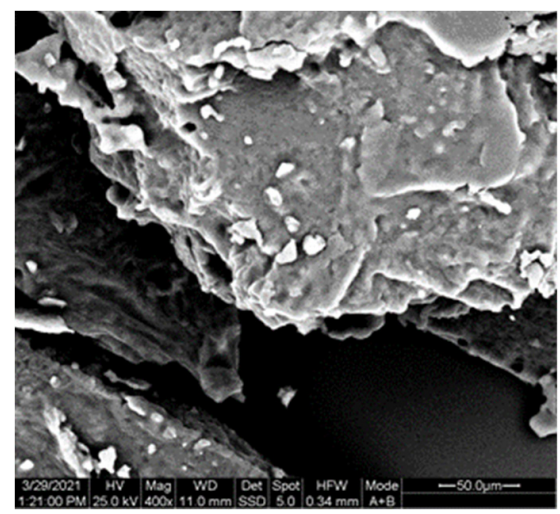

(f)

Figure 9. SEM images of R2_165_6_20 samples $(\mathbf{a}-\mathbf{c})$ and PA612_168_5_20 samples (d-f).

Turning to the end-group analysis the primary data are given graphically in Figure 10. The molecular size is expressed as number average molecular weight $\left(\overline{\mathrm{M}_{\mathrm{n}}}\right)$, in the range of 1300 to $5300 \mathrm{~g} \mathrm{~mol}^{-1}$ (Table 7). More importantly, both Table 7 and Figure 10 show that the end-groups imbalance $D$ is minimized at $165^{\circ} \mathrm{C}$ for the fossil-based products thus ensuring further reaction if needed. On the other hand, the highest molecular weight for both grades is obtained at $160{ }^{\circ} \mathrm{C}\left(4800 \mathrm{~g} \mathrm{~mol}^{-1}\right.$ for the fossil-based PA 612 and $5300 \mathrm{~g} \mathrm{~mol}^{-1}$ for the bio-based) due to the much higher reaction time ( $24 \mathrm{~h}$ compared to 5 or $6 \mathrm{~h}$ at 165 or $168^{\circ} \mathrm{C}$ respectively). For the shorter time runs the molecular weight increases significantly by increasing the reaction temperature only by $3^{\circ} \mathrm{C}$, as it is demonstrated by the calculated $\overline{\mathrm{M}_{\mathrm{n}}}$ (from 1300 to $4600 \mathrm{~g} \mathrm{~mol}^{-1}$ for the fossil-based PA612 and from 2700 to $3900 \mathrm{~g} \mathrm{~mol}^{-1}$ for the bio-based one), due to higher reaction rate. In other words, it is confirmed again that the DSSP of nylon salts have a "very high temperature coefficient" as already discussed in Section 3.2.1. Finally, viscosity data confirm the discussion. 


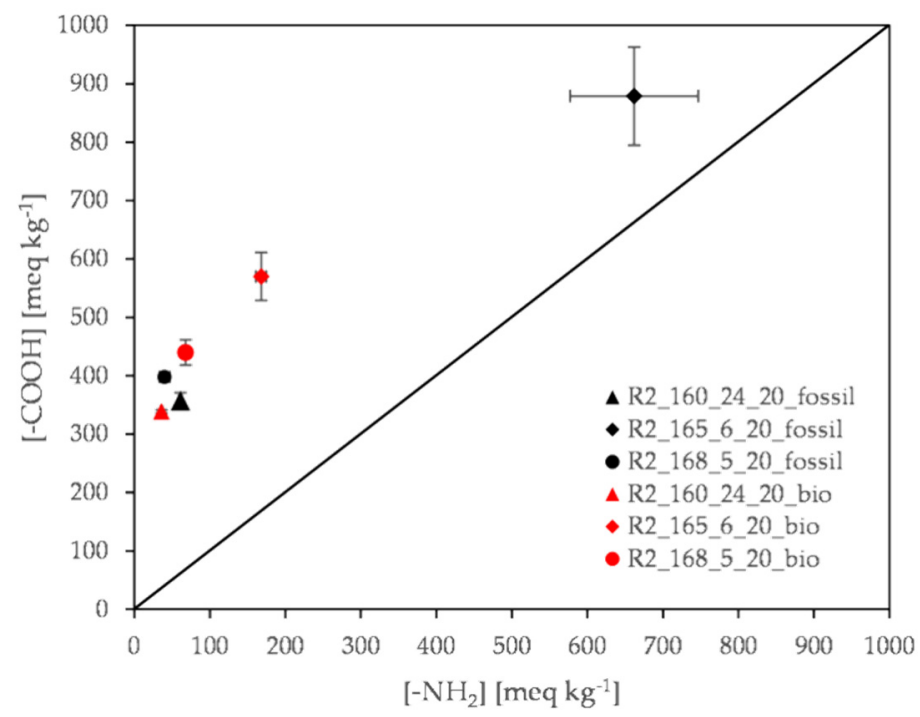

Figure 10. Evaluation of time-temperature profiles tested: amine and carboxyl end group concentration of R2 products.

Table 7. Evaluation of time-temperature profiles tested: molecular size and end-group imbalance of $\mathrm{R} 2$ products.

\begin{tabular}{|c|c|c|c|c|c|c|}
\hline & \multicolumn{2}{|c|}{$\begin{array}{c}{[\eta]} \\
\left(\mathrm{dL}^{-1}\right)\end{array}$} & \multicolumn{2}{|c|}{$\begin{array}{c}\overline{M_{n}} \\
\left(\mathrm{~kg} \mathrm{~mol}^{-1}\right) *\end{array}$} & \multicolumn{2}{|c|}{$\begin{array}{c}\mathrm{D}=[\mathrm{COOH}]-\left[\mathrm{NH}_{2}\right] \\
\left(\mathrm{meq} \mathrm{kg}^{-1}\right)\end{array}$} \\
\hline & fossil & bio & fossil & bio & fossil & bio \\
\hline R2_160_24_20 & $0.480 \pm 0.002$ & $0.610 \pm 0.006$ & 4800 & 5350 & 296 & 303 \\
\hline R2_165_6_20 & $0.251 \pm 0.020$ & $0.387 \pm 0.021$ & 1300 & 2700 & 217 & 402 \\
\hline R2_168_5_20 & $0.410 \pm 0.035$ & $0.475 \pm 0.016$ & 4550 & 3950 & 358 & 372 \\
\hline
\end{tabular}

$* \overline{\mathbf{M}_{\mathbf{n}}}$ was calculated by end-group determination.

DSC spectra of the obtained products present double melting phenomena as has been already discussed in the micro scale runs (Section 3.2.2). As to their melting point (Table 8), no significant difference between the alternative PA 612 grades was observed as all samples exhibit melting points around $217-220^{\circ} \mathrm{C}$, which are comparable to literature and commercial values. On the other hand, crystallinity values remain in the range 18 to $27 \%$ while for commercial fossil-based polyamides typically do not exceed $40 \%$ and for bio-based polyamides do not exceed $30 \%[50,51]$. This might be attributed to the lower molecular weight of our polyamides.

Table 8. Evaluation of time-temperature profiles tested: thermal properties of R2 products.

\begin{tabular}{|c|c|c|c|c|c|c|c|c|c|c|c|c|}
\hline & \multicolumn{2}{|c|}{$\begin{array}{c}T_{m} \\
\left({ }^{\circ} \mathrm{C}\right)\end{array}$} & \multicolumn{2}{|c|}{$\begin{array}{c}\Delta H_{m} \\
\left(\mathrm{Jg}^{-1}\right)\end{array}$} & \multicolumn{2}{|c|}{$\begin{array}{c}X_{c} \\
(\%)\end{array}$} & \multicolumn{2}{|c|}{$\begin{array}{c}T_{d} \\
\left({ }^{\circ} \mathrm{C}\right)\end{array}$} & \multicolumn{2}{|c|}{$\begin{array}{l}T_{d, 5 \%} \\
\left({ }^{\circ} \mathrm{C}\right)\end{array}$} & \multicolumn{2}{|c|}{$\begin{array}{c}\text { Residue } \\
\text { (\%) }\end{array}$} \\
\hline & fossil & bio & fossil & bio & fossil & bio & fossil & bio & fossil & bio & fossil & bio \\
\hline R2_160_24_20 & 220 & 217 & 50 & 69 & 19 & 27 & 455 & 448 & 374 & 378 & 3 & 3 \\
\hline R2_165_6_20 & 217 & 217 & 48 & 58 & 18 & 22 & 457 & 454 & 378 & 379 & 3 & 3 \\
\hline R2_168_5_20 & 209 & 218 & 58 & 48 & 22 & 19 & 453 & 448 & 376 & 380 & 2 & 3 \\
\hline
\end{tabular}

\subsubsection{Effect of Nitrogen Flow Rate}

It is a well-known fact that in DSSP and post-SSP of polyamide salts the nitrogen flow rate is a critical parameter for ensuring an optimum end group balance. In this study, both reactors R1 and R2 were first purged with nitrogen and then a continuous flow rate at $20 \mathrm{~mL} \mathrm{~min}-1$ was set throughout the whole reaction. However, it has been referred already in literature that, for the DSSP of PA 6T and PA 4T salts, some runs have been carried out at zero flow rate in an effort to reduce diamine loss and avoid SMT [28,30]. 
The same approach has been tested here modifying the polymerization run [R2_165_6_20] (Tables 5 or 7) with a new one: [R2_165_6_0], i.e., stopping nitrogen flow rate after purging. It is worthwhile to note that the products of the chosen run showed a minimization of $D$, thus permitting continuation of the reaction in a second stage if needed.

The results, first on maintaining the solid state, revealed that both fossil- and bio-based products provided a similar macroscopic picture at 20 or $0 \mathrm{~mL} \mathrm{~min}^{-1}$ flow rate. Some partial melting close to the reactor walls was only observed [16].

Turning to the molecular size of the DSSP products, in Table 9 the calculated $\overline{\mathrm{M}_{\mathrm{n}}}$ are quoted. These data are based on both end-groups concentrations presented graphically in Figure 11. Intrinsic viscosity $[\eta]$ data are also given for comparison. It is very impressive that abandoning the nitrogen flow leads to a very significant increase of the $\overline{\mathrm{M}_{\mathrm{n}}}$ and $[\eta]$, while $D$ decreases however slightly. This behavior is valid for the fossil-based salt while the qualitative picture provided for the bio-based grade is similar, though not so impressive or consistent.

Table 9. Effect of nitrogen flow rate: molecular size and end-groups imbalance of DSSP products.

\begin{tabular}{|c|c|c|c|c|c|c|}
\hline & \multicolumn{2}{|c|}{$\begin{array}{c}{[\eta]} \\
\left(\mathrm{dL} \mathrm{g}^{-1}\right)\end{array}$} & \multicolumn{2}{|c|}{$\begin{array}{c}\overline{M_{n}} \\
\left(\mathrm{~kg} \mathrm{~mol}^{-1}\right) *\end{array}$} & \multicolumn{2}{|c|}{$\begin{array}{c}D=[\mathrm{COOH}]-\left[\mathrm{NH}_{2}\right] \\
\left(\mathrm{meq} \mathrm{kg}^{-1}\right)\end{array}$} \\
\hline & fossil & bio & fossil & bio & fossil & bio \\
\hline R2_165_6_20 & $0.251 \pm 0.020$ & $0.387 \pm 0.021$ & 1300 & 2700 & 217 & 402 \\
\hline R2_165_6_0 & $0.448 \pm 0.020$ & $0.433 \pm 0.085$ & 2150 & 2050 & 208 & 320 \\
\hline
\end{tabular}

$* \overline{\mathbf{M}_{\mathbf{n}}}$ was calculated by end-group determination.

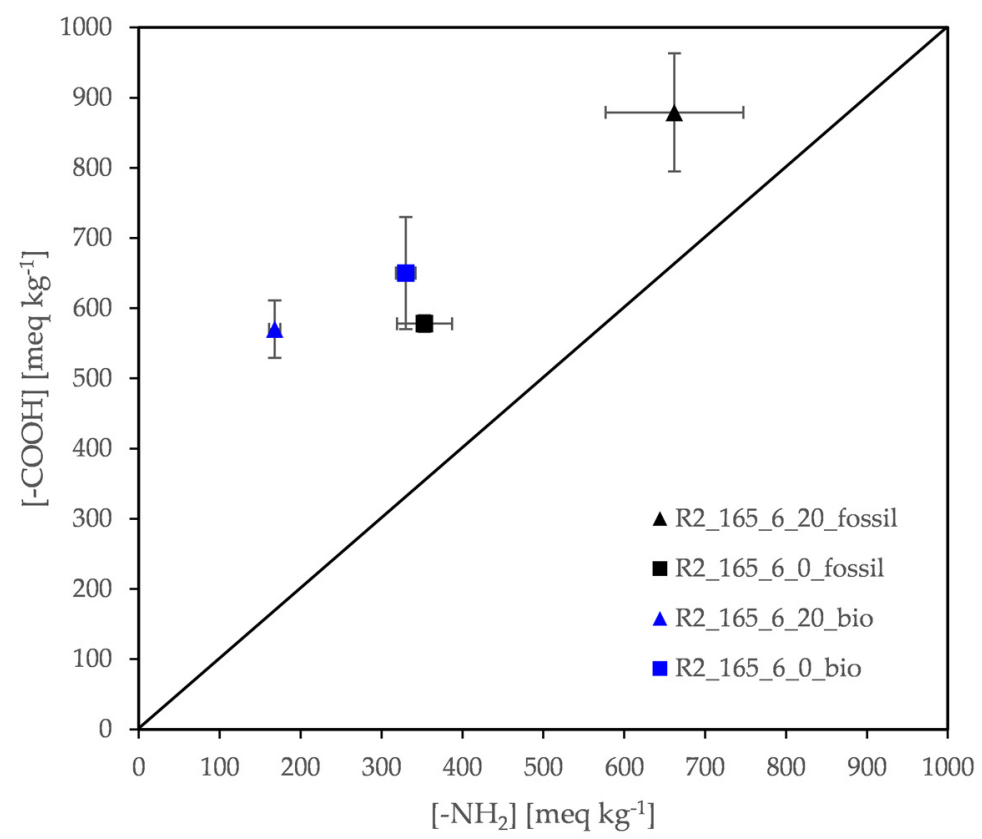

Figure 11. Effect of nitrogen flow rate: amine and carboxyl end group concentration of DSSP products.

In the polyamide industry starting from salts, to attain high molecular weights a two-step process is required. A typical example is the commercial production of Nylon 66 [12,36,52-59]: the polymerization proceeds initially in an aqueous solution, then water is removed while the reaction turns to the melt state, followed at the end by the so called "solid state finishing", i.e., a post SSP step. The latter serves in avoiding unnecessary and harmful exposure of the material at high temperatures. On the other hand, polycondensation processes, mainly on polyesters, are under investigation, based on the same approach: the reaction occurs in steps at increasing temperatures [60]. 
To apply the aforementioned route in polyamides a critical prerequisite is necessary: the stoichiometric balance between amine and carboxyl groups should remain as close as possible to equimolar conditions, following Flory's kinetics [61].

In conclusion, the fossil-based PA product under the code conditions [R2_165_6_0] presented the best overall performance, for being the starting material in a subsequent DSSP while testing further Reactor R2.

\subsubsection{Demonstration of a Feasible Two-Step DSSP Process}

To fulfill the aforementioned prerequisite on $D$, the addition of some amine preceding the post SSP step comprises a widely applied route. This easily corrects D while being very successful in the polyamide industry for decades [30,62-64]. In other words, amine addition into already polymerized samples, subjected then to post-SSP, has been proved very attractive. In this context and to demonstrate a feasible industrial process (Table 1), $2 \%$ of HMD was added into the [R2_165_6_0] product of fossil-based PA612, being the sample with the lowest end-group deviation as mentioned already. After the amine addition, the sample was polymerized at $170^{\circ} \mathrm{C}$ for $4 \mathrm{~h}$ again under zero nitrogen flow.

The post-SSP product was received as solid free-flowing particles, retaining their original morphology throughout the reaction. Amine addition has been proven successful in increasing the molecular weight of the final product while maintaining a good end-group balance (Figure 12). In particular, a 17\% increase in intrinsic viscosity was reported, while the number average molecular weight almost tripled to $6300 \mathrm{~g} \mathrm{~mol}^{-1}$ (Table 10). Finally, the final product contained a fair amount of end-groups (114 meq $\mathrm{kg}^{-1}$ amine groups and $202 \mathrm{meq} \mathrm{kg}^{-1}$ carboxyl groups), meaning that it is suitable for further polymerization.

Thus, for the first time an aliphatic nylon salt, the hexamethylene diammonium dodecanoate, has been polymerized via direct solid state polymerization, i.e., starting from free-flowing salt crystals and ending to polymer particles. The process itself is environmentally friendly, comprising of two isothermal steps at low temperatures, for short times and at atmospheric pressure. Finally, the design of the Reactor R2, in contrast with a conventional autoclave R1, catalytically contributed to the success of this project.

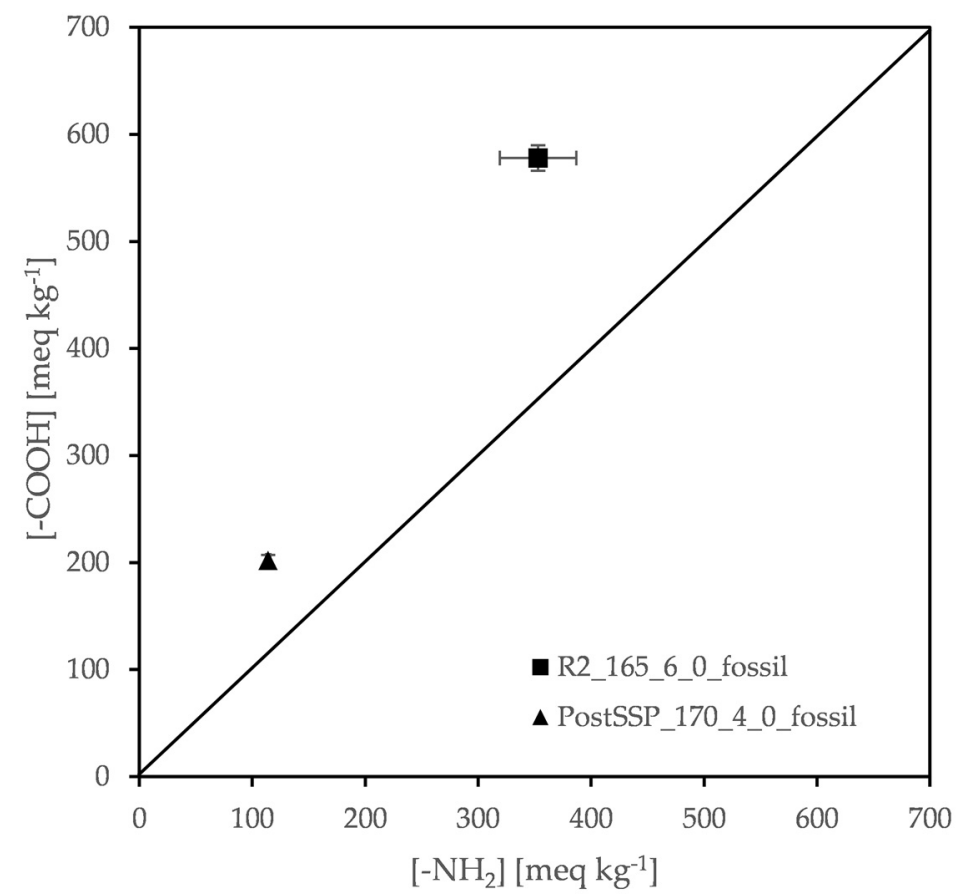

Figure 12. The two-step DSSP process: amine and carboxyl end group concentration of one-step and two-step DSSP products. 
Table 10. The two-step DSSP process: molecular size and end-group imbalance of one-step and two-step DSSP products.

\begin{tabular}{|c|c|c|c|}
\hline & $\begin{array}{c}{[\eta]} \\
\left(\mathrm{dL} \mathrm{g}^{-1}\right)\end{array}$ & $\begin{array}{c}\overline{M_{n}} \\
\left(\mathrm{~kg} \mathrm{~mol}^{-1}\right) *\end{array}$ & $\begin{array}{c}D=[\mathrm{COOH}]-\left[\mathrm{NH}_{2}\right] \\
\left(\mathrm{meq} \mathrm{kg}^{-1}\right)\end{array}$ \\
\hline \multicolumn{4}{|c|}{ Fossil—based } \\
\hline R2_165_6_0 & $0.448 \pm 0.020$ & 2100 & 208 \\
\hline Post_SSP_R2_170_4_0 & $0.522 \pm 0.015$ & 6350 & 87 \\
\hline
\end{tabular}

${ }^{*} \overline{\mathbf{M}_{\mathbf{n}}}$ was calculated by end-group determination.

\section{Conclusions}

The aim of this work was to apply DSSP on aliphatic nylon salts. The case of the PA 612 salt, fossil-based or bio-based, was chosen. The process should bypass the SMT phenomena occurring in DSSP. In this context, emphasis was given first to reactor design, being the critical issue for understanding and controlling inherent kinetics, amine loss and byproduct diffusion. Different time-temperature profiles were tested first at microscale and then at laboratory scale via two alternative reactors. Occurrence of SMT, when scaling up from microscale to a conventional laboratory autoclave, was in harmony with similar studies on numerous aliphatic nylon salts. The picture changed when using the new laboratory reactor. A series of scouting experiments on the critical reaction parameters concluded to the demonstration of a real DSSP process, starting from crystals of PA 612 salt and ending to PA 612 particles without any intermediate melt stages. Two isothermal steps, while correcting amine end-groups content between, have been involved. Finally, the fossil-based PA 612 salt provided better end-groups imbalance than the bio-based salt.

Author Contributions: Conceptualization, C.D.P.; methodology, C.D.P., A.D.M., A.D.P. and S.N.V.; resources, C.D.P. and A.D.P.; data curation, A.D.M.; writing-original draft preparation, A.D.M.; writing-review and editing, C.D.P.; supervision, C.D.P., A.D.P. and S.N.V.; project administration, C.D.P. All authors have read and agreed to the published version of the manuscript.

Funding: This research received no external funding.

Data Availability Statement: Data is contained within the article.

Conflicts of Interest: The authors declare no conflict of interest.

\section{References}

1. Kampouris, E.M. New solid state polyamidation process. Polymer 1976, 17, 409-412. [CrossRef]

2. Papaspyrides, C.D.; Kampouris, E.M. Solid-state polyamidation of dodecamethylenediammonium adipate. Polymer 1984, 25, 791-796. [CrossRef]

3. Kampouris, E.M.; Papaspyrides, C.D. Solid state polyamidation of nylon salts: Possible mechanism for the transition solid-melt. Polymer 1985, 26, 413-417. [CrossRef]

4. Papaspyrides, C.D.; Kampouris, E.M. Influence of acid catalysts on the solid-state polyamidation of dodecamethylenediammonium adipate. Polymer 1986, 27, 1433-1436. [CrossRef]

5. Papaspyrides, C.D.; Kampouris, E.M. Influence of metal catalysts on solid state polyamidation of nylon salts. Polymer 1986, 27, 1437-1440. [CrossRef]

6. Papaspyrides, C.D. Solid-state Polyamidation of Hexamethylenediammonium Adipate in the Presence of Acid Catalysts. I. Preparation of the Catalyst Containing Monomer. J. Polym. Sci. Part C Polym. Lett. 1987, 25, 363-367. [CrossRef]

7. Papaspyrides, C.D. Solid-state polyamidation of nylon salts. Polymer 1988, 29, 114-117. [CrossRef]

8. Papaspyrides, C.D. Solid state polyamidation of aliphatic diamine aliphatic diacid salts: A generalized mechanism for the effect of polycondensation water on reaction behaviour. Polymer 1990, 31, 490-495. [CrossRef]

9. Papaspyrides, C.D. Solid-state polyamidation of unsaturated nylon salts: The role of polycondensation water. Polymer 1990, 31, 496-500. [CrossRef]

10. Papaspyrides, C.D. Solid State Polyamidation Processes. Polym. Int. 1992, 29, 293-298. [CrossRef]

11. Katsikopoulos, P.V.; Papaspyrides, C.D. Solid-state Polyamidation of Hexamethylenediammonium Adipate. II. The Influence of Acid Catalysts. J. Polym. Sci. Part A Polym. Chem. 1994, 32, 451-456. [CrossRef]

12. Papaspyrides, C.D. Solid State Polyamidation. In Polymeric Materials Encyclopedia; Salamone, J.C., Ed.; CRC Press: Boca Raton, FL, USA, 1996; pp. 7819-7831.

13. Bletsos, I.V.; Papaspyrides, C.D. Low Water Diamine-Dicarboxylic Acid Salt Preparation. U.S. Patent 5,801,278, 1 February 1998. 
14. Tynan, D.G.; Papaspyrides, C.D.; Bletsos, I.V. Polymer Mixing Apparatus and Method. U.S. Patent 5,941,634, 24 August 1999.

15. Papaspyrides, C.D.; Vouyiouka, S.N.; Bletsos, I.V. New Process for the Production of Dry Hexamethylenediammonium Adipate. J. Appl. Polym. Sci. 2003, 88, 1252-1257. [CrossRef]

16. Papaspyrides, C.D.; Vouyiouka, S.N.; Bletsos, I.V. Preparation of Polyhexamethyleneadipamide Prepolymer by a LowTemperature Process. J. Appl. Polym. Sci. 2004, 29, 301-306. [CrossRef]

17. Vouyiouka, S.N.; Karakatsani, E.K.; Papaspyrides, C.D. Solid state polymerization. Prog. Polym. Sci. 2005, 30, 10-37. [CrossRef]

18. Vouyiouka, S.N.; Papaspyrides, C.D.; Weber, J.; Marks, D. Polyamide Solid State Polymerization: Evaluation of Pertinent Kinetic Models. J. Appl. Polym. Sci. 2005, 97, 671-681. [CrossRef]

19. Vouyiouka, S.N.; Papaspyrides, C.D.; Pfaendner, R. Catalyzed Solid-State Polyamidation. Macromol. Mater. Eng. 2006, 291, 1503-1512. [CrossRef]

20. Papaspyrides, C.D.; Vouyiouka, S.N.; Bletsos, I.V. New aspects on the mechanism of the solid state polyamidation of PA 6,6 salt. Polymer 2006, 47, 1020-1027. [CrossRef]

21. Vouyiouka, S.N.; Koumantarakis, E.; Papaspyrides, C.D. Preparation and Solid-State Polyamidation of Hexamethylenediammonium Adipate: The Effect of Sodium 5-Sulfoisophthalic Acid. J. Appl. Polym. Sci. 2007, 104, 1609-1619. [CrossRef]

22. Vouyiouka, S.N.; Papaspyrides, C.D.; Weber, J.N.; Marks, D.N. Solid state post-polymerization of PA 6,6: The effect of sodium 5-sulfoisophthalic acid. Polymer 2007, 48, 4982-4989. [CrossRef]

23. Fink, J.; Phaedner, R.; Simon, D.; Papaspyrides, C.; Vouyiouka, S. Process for the Preparation of Polyamides in the Presence of a Phosphonate. W.O. Patent 006,647-A1, 18 January 2007.

24. Papaspyrides, C.; Vouyiouka, S. Solid State Polymerization; Papaspyrides, C.D., Vouyiouka, S.N., Eds.; John Wiley \& Sons, Inc.: Hoboken, NJ, USA, 2009.

25. Boussia, A.C.; Vouyiouka, S.N.; Porfiris, A.D.; Papaspyrides, C.D. Long-Aliphatic-Segment Polyamides: Salt Preparation and Subsequent Anhydrous Polymerization. Macromol. Mater. Eng. 2010, 295, 812-821. [CrossRef]

26. Papaspyrides, C.; Vouyiouka, S. Encyclopedia of Polymer Science and Technology, 4th ed.; John Wiley \& Sons, Inc.: Hoboken, NJ, USA, 2011.

27. Boussia, A.C.; Konstantakopoulou, M.O.; Vouyiouka, S.N.; Papaspyrides, C.D. Nanocatalysis in Polyamide 6.6 Solid-State Polymerization. Macromol. Mater. Eng. 2011, 296, 168-177. [CrossRef]

28. Papaspyrides, C.D.; Porfyris, A.D.; Vouyiouka, S.; Rulkens, R.; Grolman, E.; Vanden Poel, G. Solid state polymerization in a micro-reactor: The case of poly (tetramethylene terephthalamide). J. Appl. Polym. Sci. 2016, 1, 1-14. [CrossRef]

29. Papaspyrides, C.D.; Porfyris, A.D.; Rulkens, R.; Grolman, E.; Kolkman, A.J. The Effect of Diamine Length on the Direct Solid State Polycondensation of Semi-Aromatic Nylon Salts. J. Polym. Sci. Part A Polym. Chem. 2016, 54, 2493-2506. [CrossRef]

30. Porfyris, A.D.; Papaspyrides, C.D.; Rulkens, R.; Grolman, E. Direct solid state polycondensation of tetra- and hexamethylenediammonium terephthalate: Scaling up from the TGA micro-reactor to a laboratory autoclave. J. Appl. Polym. Sci. 2017, 134, 45080. [CrossRef]

31. Porfyris, A.D.; Vouyiouka, S.; Papaspyrides, C.; Rulkens, R.; Grolman, E.; Vanden Poel, G. Investigating alternative routes for semi-aromatic polyamide salt preparation: The case of tetramethylenediammonium terephthalate (4T salt). J. Appl. Polym. Sci. 2016, 42987, 1-11. [CrossRef]

32. Volokhina, A.V.; Kudryavtsev, G.I.; Skurato, S.M.; Bonetskaya, A.K. The polyamidation process in the solid state. J. Polym. Sci. 1961, 53, 289-294. [CrossRef]

33. Volokhina, A.; Kudryavstev, G.; Raeva, M.; Bogdanov, M.; Kalmykova, V.; Mandrosova, F.; Okromchedidze, N. Polycondensation reactions in the solid phase: V. Polycondensation of the diamine salts of therephthalic acid and hexahydroterephthalic acids in the solid state. Khim. Volokna. 1964, 6, 30-33.

34. Pipper, G.; Mueller, W.F.; Dauns, H. Catalytic Solid State Process for the Preparation of Linear Polyamides. U.S. Patent 5,128,442, 7 July 1992.

35. Kosinski, L.; Soelch, R.R. Low Temperature Nylon Polymerization Process. W.O. Patent 94/21711, 29 September 1994.

36. Weber, J. Kirk-Othmer Encyclopedia of Chemical Technology; Wiley: New York, NY, USA, 1996; Volume 19, p. 463.

37. Zheng, W.; McAuley, K.B.; Marchildon, E.K.; Yao, K.Z. Effects of End-Group Balance on Melt-Phase Nylon 612 Polycondensation: Experimental Study and Mathematical Model. Ind. Eng. Chem. Res. 2005, 44, 2675-2686. [CrossRef]

38. Kumar, S.; Maiti, S.N.; Satapathy, B.K. Super-toughening polyamide-612 by controlling dispersed phase domain size: Essential work of fracture assessment. Mater. Des. 2014, 62, 382-391. [CrossRef]

39. Rusu, G.; Rusu, E. Evaluation of thermal and dielectric behaviour of some anionic nylon 612 copolymers. Mater. Des. 2010, 31, 4601-4610. [CrossRef]

40. Kumar, S.; Satapathy, B.K.; Maiti, S.N. Correlation of morphological parameters and mechanical performance of polyamide612/poly (ethylene-octene) elastomer blends. Polym. Adv. Technol. 2013, 24, 511-519. [CrossRef]

41. Song, P.; Wang, C.; Chen, L.; Zheng, Y.; Liu, L.; Wu, Q.; Huang, G.; Yu, Y.; Wang, H. Thermally stable, conductive and flameretardant nylon 612 composites created by adding two-dimensional alumina platelets. Comp. Part A App. Sci. Manuf. 2017, 97, 100-110. [CrossRef]

42. Billmeyer, F.W. Methods for Estimating Intrinsic Viscosity. J. Polym. Sci. 1949, 4, 83-86. [CrossRef]

43. Shi, Y. Phase behavior of polyamide 6/612 blends. Plast. Eng. 2016, 72, 46-49. [CrossRef] 
44. Ikawa, I. High Pressure Solid State Polymerization of Polyamide Monomer Crystals. In Solid State Polymerization; Papaspyrides, C., Vouyiouka, S., Eds.; John Wiley \& Sons: Hoboken, NJ, USA, 2009; p. 181.

45. Cui, X.; Li, W.; Yan, D.; Yuan, C.; Di Silvestro, G. Synthesis and Characterization of Polyamides X 18. J. Appl. Polym. Sci. 2005, 98, 1565-1571. [CrossRef]

46. Cui, X.; Yan, D. Synthesis and Characterization of Novel Odd-Even Nylons Based on Eicosanedioic Acid. J. Appl. Polym. Sci. 2004, 93, 2066-2071. [CrossRef]

47. Cui, X.; Yan, D.; Xiao, D. Synthesis and characterization of novel polyamides based on tridecanedioic acid: Nylons $313,513,613$, 7 13, 9 13, 10 13, 11 13. e-Polymers 2004, 13, 7-15. [CrossRef]

48. Chen, G.; Tang, K.; Niu, G.; Pan, K.; Feng, X.; Zhang, L. Synthesis and Characterization of the Novel Nylon 126 Based on 1,12Diaminododecane. Polym. Eng. Sci. 2019, 59, 192-197. [CrossRef]

49. Nguyen, P.H.; Spoljaric, S.; Seppälä, J. Redefining polyamide property profiles via renewable long-chain aliphatic segments: Towards impact resistance and low water absorption. Eur. Polym. J. 2018, 109, 16-25. [CrossRef]

50. Patil, A.M. Synthesis and Characterization of Bio-based Polyester and Polyamide from Citric Acid and Mannitol. Orient. J. Chem. 2018, 34, 538-543. [CrossRef]

51. Pagacz, J.; Raftopoulos, K.N.; Leszczyn, A.; Pielichowski, K. Bio-polyamides based on renewable raw materials. Glass transition and crystallinity studies. J. Therm. Anal. Calorim. 2016, 123, 1225-1237. [CrossRef]

52. Larsen, H. Preparation of Salt Solution Useful for Making Nylon. U.S. Patent 4,442,260, 10 April 1984.

53. Alsop, A.W.; Blanchard, E.N.; Cohen, J.D.; Young Lin, C.; Marks, D.N.; Stouffer, J.M. Process for Preparing Polyamides. U.S. Patent 6,069,228, 30 May 2000.

54. Dujari, R.; Cramer, G.; Marks, D. Method for Solid Phase Polymerization. W.O. Patent 98/23666, 4 June 1998.

55. Monroe, G.K. Solid Phase Polymerization of Polyamides. U.S. Patent 3,031,433, 24 April 1962.

56. Greenewalt, C.E. Process for Preparing Linear Polyamides. U.S. Patent 2,245,129, 10 June 1941.

57. Bush, G.E.; Schwier, C.E.; Lembcke, R.M.; Cook, S.W. Continuous Polyamidation Process. U.S. Patent 6,169,162 B1, 2 January 2001.

58. Pipper, G. Process for the Production of Linear Polyamides. U.S. Patent 0455066 A1, 19 April 1991.

59. Lang, J.J. Low Temperature Manufacturing Process for Nylon. W.O. Patent 96/16108, 30 June 1996.

60. Papaspyrides, C.D.; Vouyiouka, S.; Georgousopoulou, I.N.; Marinkovic, S.; Estrine, B.; Joly, C.; Dole, P. Feasibility of Solid-state post polymerization on fossil- and bio-based poly (butylene succinate) including polymer upcycling routes. Ind. Eng. Chem. Res. 2016, 55, 5832-5842. [CrossRef]

61. Flory, P. Principles of Polymer Chemistry; Cornell University Press: Ithaca, NY, USA, 1975; pp. 75-83, 317-325.

62. Van Laarhoven, B.; Stoelwinder, C.J.C.; Helmsing, M. Process for Preparing a Polyamide, a Nylon Salt to Be Used Therein and a Process for Making the Salt. U.S. Patent 0210850 A1, 27 June 2017.

63. Rulkens, R.; Grolman, E.; Poel Vanden, G.; Kierkels, R.; Cuypers, T.; Papaspyrides, C.; Porfyris, A. Process for Producing a Semi-Aromatic Semi-Crystalline Polyamide. W.O. Patent 2014/202506 A1, 24 December 2014.

64. Kuehn, F.; Rulkens, R. Process for the Preparation of Polyamide Granules. W.O. Patent 0,056,803A1, 28 September 2000. 